\title{
Kinship and Incestuous Crime in Colonial Guatemala
}

Kinship and Incestuous Crime in Colonial Guatemala examines social relations in colonial Guatemala through the lens of incest. Using a combination of qualitative and quantitative analyses of incest trials from the Spanish secular courts, this study shows that incest codes were not homogenous nor were its various forms equally condemned. Further, incest codes and the criminal process impacted the articulation of kinship and contributed to the racialization of kin behavior. Colonial actors of all sorts were proficient at using these types of distinctions as they negotiated various crises in their lives. The models of relatedness created within incestuous crime ultimately foreshadowed changes in marriage proscriptions and continued racial polarization following independence from Spain. Overall, this study demonstrates how the lens of incest can add further nuance to our understanding of social relations in a given area. Incest codes force latent divisions between kin to the surface and can provide individuals with multiple avenues to creatively manage interpersonal relationships. They also afford a fruitful arena in which to explore social inequalities in society and mechanisms of culture change. This book will appeal to anyone interested in Latin America or engaged in the fields of kinship, gender, or sexuality studies.

Sarah N. Saffa is currently a Visiting Scholar at Johns Hopkins University. 


\section{Routledge Studies in the History of the Americas}

10 The Global Perspective of Urban Labor in Mexico City, 1910-1929

El Mundo al Revés

Stephan Fender

11 The Last Year of President Kennedy and the "Multiple Path" Policy Toward Cuba

Håkan Karlsson and Tomás Diez Acosta

12 The Monroe Doctrine in a Contemporary Perspective Denneth M. Modeste

13 Free People of Color in the Spanish Atlantic

Race and Citizenship, 1780-1850

Federica Morelli

14 Hearing Enslaved Voices

African and Indian Slave Testimony in British and

French America, 1700-1848

Edited by Sophie White and Trevor Burnard

15 Kinship and Incestuous Crime in Colonial Guatemala Sarab N. Saffa

16 Education in Revolutionary Struggles

Iván Illich, Paulo Freire, Ernesto Guevara and Latin America Thought

Andrés Donoso Romo

For more information about this series, please visit: https://www.routledge. com/Routledge-Studies-in-the-History-of-the-Americas/bookseries/RSHAM 


\section{Kinship and Incestuous Crime in Colonial Guatemala}

Sarah N. Saffa 
First published 2021

by Routledge

52 Vanderbilt Avenue, New York, NY 10017

and by Routledge

2 Park Square, Milton Park, Abingdon, Oxon, OX14 4RN

Routledge is an imprint of the Taylor \& Francis Group, an informa business

(C) 2021 Taylor \& Francis

The right of Sarah N. Saffa to be identified as author of this work has been asserted in accordance with sections 77 and 78 of the Copyright, Designs and Patents Act 1988.

All rights reserved. No part of this book may be reprinted or reproduced or utilised in any form or by any electronic, mechanical, or other means, now known or hereafter invented, including photocopying and recording, or in any information storage or retrieval system, without permission in writing from the publishers.

Trademark notice: Product or corporate names may be trademarks or registered trademarks, and are used only for identification and explanation without intent to infringe.

Library of Congress Cataloging-in-Publication Data

Names: Saffa, Sarah N., 1985- author.

Title: Kinship and incestuous crime in colonial Guatemala / Sarah N. Saffa.

Description: New York, NY : Routledge, an imprint of the Taylor \& Francis Group, an Informa Business, 2021. I

Series: Routledge studies in the history of the americas; 15 ।

Includes bibliographical references and index.

Identifiers: LCCN 2020022673 (print) I

LCCN 2020022674 (ebook) | ISBN 9780367464424 (hardback) |

ISBN 9781003028789 (ebook) I ISBN 9781000172621

(adobe pdf) I ISBN 9781000172638 (mobi) |

ISBN 9781000172645 (epub)

Subjects: LCSH: Incest-Law and legislation-Guatemala-

History. I Sex crimes-Law and legislation-Guatemala-

History. | Paternity-Guatemala-History. |

Kinship (Law) - Guatemala-History.

Classification: LCC KGD5564 .S24 2021 (print) I

LCC KGD5564 (ebook) I DDC 345.7281/02536-dc23

LC record available at https://lccn.loc.gov/2020022673

LC ebook record available at https://lccn.loc.gov/2020022674

ISBN: 978-0-367-46442-4 (hbk)

ISBN: 978-1-003-02878-9 (ebk)

Typeset in Sabon

by codeMantra 
For Zach

and

all of my

stepframily-in-law 

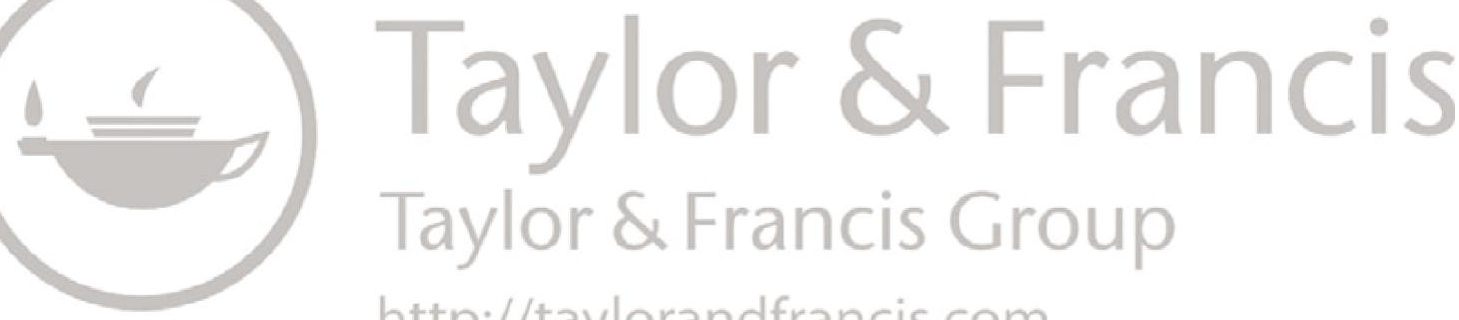

http://taylorandfrancis.com 


\section{Contents}

List of Figures ix

List of Tables $\quad \mathrm{xi}$

1 Introduction: "I Am Not Your Father" 1

2 Social Relations in Colonial Spanish America 14

3 Incest and the Law 39

4 Blood Is Thicker than Water 61

5 Relative and Strategic Kinship 85

6 Incest and Indianness 111

7 Conclusion 136

Appendix 143

Index 161 

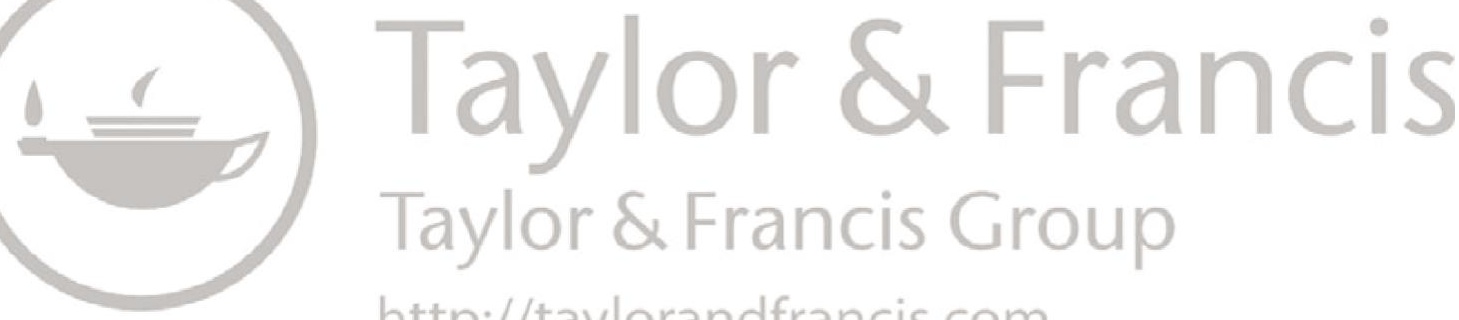

http://taylorandfrancis.com 


\section{Figures}

1.1 Modern Guatemala overlain with late colonial jurisdictional divisions (1785-1821). Jurisdictional information adapted from Komisaruk (2013, xv). Map by Zachary S. Klukkert. 

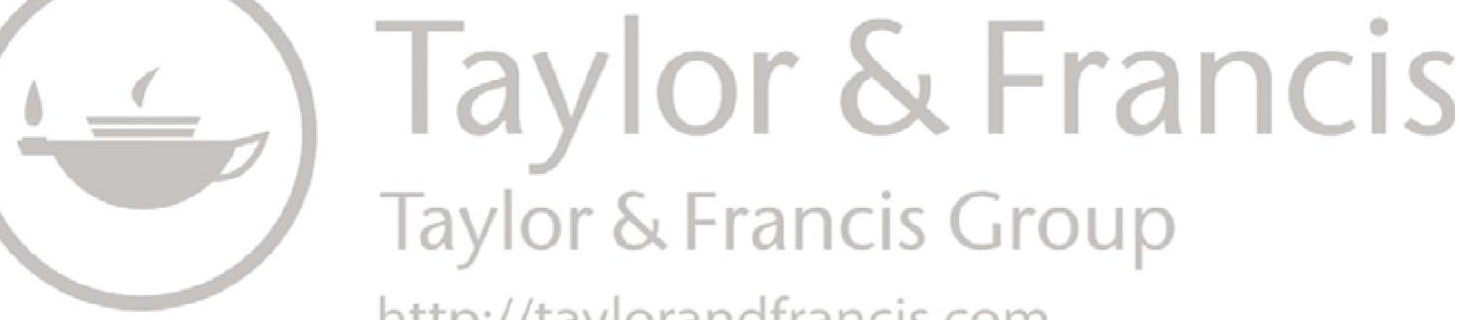

http://taylorandfrancis.com 


\section{Tables}

2.1 Incest and Sexual Violence 22

4.1 Incidents of Incest by Kinship Type 63

4.2 Incidents of Incest and Calidad 65

4.3 Plaintiff(s) Type in Incest Cases $\quad 73$

4.4 Case Numbers by Plaintiff(s) Type 74

4.5 Plaintiffs by Gender 74

4.6 Case Numbers of Plaintiffs by Gender 74

6.1 Male Defendants and the Ignorance Defense 124

6.2 Female Defendants and the Ignorance Defense 125

6.3 Incestuous Rapists, Victims, and the Ignorance Defense 125 

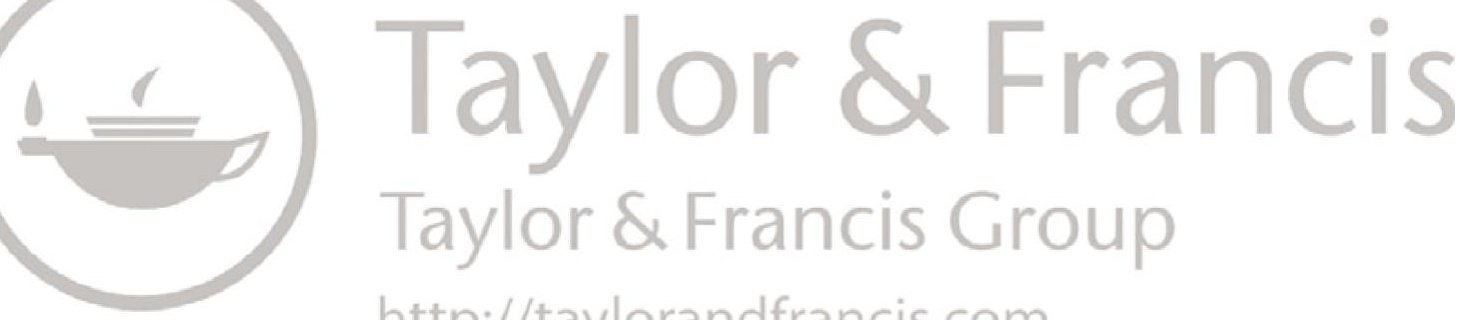

http://taylorandfrancis.com 


\title{
1 Introduction
}

\author{
"I Am Not Your Father"
}

\section{Introduction}

In 1810, José Rumualdo Fuentes denounced his father Vicente to colonial authorities for the rape of his wife-Vicente's daughter-in-lawon two separate occasions. ${ }^{1}$ José claimed that Vicente annulled both of their marriages through his actions and requested his exile. In legal jargon, Vicente had committed incest in the first degree. The victim in this case, María Rosalía Surqueah, ${ }^{2}$ tried to interrupt the sexual violence, evidently referring to Vicente as her "father" in the process. However, Vicente had retorted that he was not her father, and her efforts to impede his attacks were ultimately unsuccessful. Rosalía believed she was pregnant from their union, though this turned out to not be the case. Vicente initially denied the accusation, suggesting that Rosalía was using him to cover up a sexual relationship with another man. However, he eventually admitted to the crime. Like many victims of sexual assault, Rosalía was equally on trial, and debate ensued as to whether or not she consented to the incest. Both Rosalía and Vicente were Indians, and defense counsel on either side drew from colonial constructions of Indianness in their attempts to exculpate their clients. Still, in the end, Vicente was sentenced to four years of imprisonment and twenty-five lashes, and Rosalía to two months of interior service in the Beaterio de Indias (house of pious Indian laywomen) and spiritual exercises. There was also a mandate for the "habilitation" of their marriages, an ecclesiastical process that allowed spouses to resume married life with one another. As it turns out, the story of this Poqomam Maya family resonated with those of many other families in colonial Guatemala. And, taken together, episodes such as these shed light on the lived experience of kinship and its intersections with a colonial regime.

Westerners ${ }^{3}$ today often associate incest with sexual intercourse between close blood relatives, but incest taboos are not uniform across time and space. For Spain and its American colonies, the legal definition of incesto ("incest") included sexual relations between various types of individuals. Among them were consanguineous, affinal, and "spiritual" kin-the latter of which were created through the Catholic 


\section{Introduction}

rites of baptism and confirmation-in addition to members of religious orders and non-Christians. Yet, analysis of incest trials from the Spanish secular courts shows that the definition of incest in colonial Guatemala was not always shared, nor were its various forms equally condemned. Further, incest codes and the criminal process impacted the articulation of kinship, with colonial actors often using the norms and nuances related to incest to their own or another's advantage. These variables also contributed to the racialization of kinship models, as individuals drew from assumptions about a relationship between Indianness and incest, even in the face of evidence to contrary. Overall, incestuous acts and the legal proceedings surrounding them reflected and constituted various aspects of social relations in colonial Guatemala and prefigured elements of social life following independence from Spain.

\section{Theory, Method, and Context}

Colonial Guatemala was a region within the viceroyalty of New Spain, which included territories within the southern United States, Mexico, Central America, and the Caribbean and Philippine seas. The Kingdom of Guatemala included the area between modern-day Chiapas and the Costa Rica-Panama border. Territories within today's nations of Guatemala, El Salvador, and Belize roughly formed the province of Guatemala within the larger Kingdom of Guatemala during the seventeenth century. Following the establishment of the intendency system in the late eighteenth century, El Salvador became its own intendency, and the province of Guatemala was reduced to areas within present-day Guatemala and Belize. All of the cases analyzed in this study took place within this province and span the years 1682-1821, the year in which independence from Spain was declared.

Colonial Guatemala was largely made up of indigenous Maya, but Spaniards (born in Spain and the Americas), Africans, and individuals of mixed descent also formed a part of the fabric of colonial society. ${ }^{4}$ There were large discrepancies in levels of education such that many individuals were illiterate, while others held professional degrees. Religious indoctrination and scrutiny by Spanish colonial authorities was uneven at best, allowing indigenous and rural areas greater liberty from the enforcement of civil and canon norms. While incest in colonial (and post-independence) New Spain has received some scholarly attention, the colonial Guatemalan region has eluded much analysis. ${ }^{5}$ Thus, this study works to fill this gap, providing not only a general framework of incest in the area for the purpose of contextualization and regional comparison but also intimate glimpses into the lives of gendered and racialized kinspersons in colonial Guatemala. 
Incest has long been intriguing to anthropologists because such taboos are evidently common to all human societies. Incest is typically understood as a proscription on sexual relations between individuals considered to be too closely related, which will vary depending on cultural and historical context. However, the term used to designate such proscriptions can also be extended to include certain non-kin, as was the case in Spanish law. Explanations for the incest taboo have varied. Some consider biological influences, such as the importance of genetic variation (via outbreeding) to the survival and adaptation of the species (see Fox 1980, 10-1). Others focus on sociocultural factors in which incest taboos serve to reduce the potential for intra-group conflict and promote inter-group alliance. ${ }^{6}$ More recently, Françoise Héritier (2002) proposed that the incest taboo derives from a universal human proclivity to categorize things as the same or different, with contact between identical bodily fluids (however defined) being the ultimate criterion for incest. Regardless of the exact mechanisms behind incest taboos, their codification is uniquely human, and they have clearly impacted social experience.

Incest naturally intersects with the concept of kinship or relatedness, ${ }^{7}$ a signature subject of the anthropological discipline because of its apparent role in human social organization. For much of anthropology's existence, kinship was conceived of as the sociocultural means of organizing the biological "facts" of procreation. In other words, kinship was ultimately rooted in sexual reproduction. Pushes towards reflexivity within the broader postmodern movement led to criticism that kinship was an ethnocentric construct reflecting a Western worldview. Thus, it was argued that kinship should not be considered to have some pre-social, universal existence. ${ }^{8}$ Because of such debate, kinship is now viewed in more optative and fluid terms and as not necessarily tied to so-called blood relations. ${ }^{9}$ Generally speaking, there has been a shift to thinking of kinship as a process as opposed to a state of being (see Parkin and Stone 2004; Bamford and Leach 2009). At the same time, biology has reentered the equation with the understanding that human culture is not wholly removed from human evolution. However, biology in this case is seen as one potential factor underlying kinship construction and behavior-not as a universal feature of it (see Stone 2004).

While concepts of relatedness in colonial Guatemalan incest trials in many ways centered on the idea of inalienable blood ties, they were also characterized by a degree of malleability and sensitivity to context. As a result, these cases provide a ripe arena in which to view the coexistence of, and tensions between, these different forms of relating. They necessitate thinking in terms of a kinship calculus in which variables like sexual relations or criminal procedure shape the expression of relatedness in culturally predicated-though not always identical-ways. Indeed, 


\section{Introduction}

there were times when individuals came to different conclusions about the nature of a relationship.

Analysis of incestuous crime in colonial Guatemala demands a feminist perspective. Feminist anthropologists have often highlighted the role of social processes (e.g. kinship) in the production of gender asymmetries and heteronormativity. ${ }^{10}$ In colonial Guatemala, incestuous violence was gendered-victims were always women and girls, whereas perpetrators were exclusively men. Further, incestuous violence was typically enacted by father-types-fathers, stepfathers, and fathers-inlaw. Both patterns are consistent with the patriarchal ideals that infused much of colonial Latin America (cf. Herman 2000). The criminal category of incest also reinforced a heteronormative environment. Following various legal codes and the cases of incest that were brought to trial in the Guatemalan secular courts, "incest" only referred to sexual relations between male and female kin.

This topic of investigation also requires an intersectional approach. The experience of Indians in the criminal process was particularly marked. The ways in which Spanish legal authorities and defense counsel regularly portrayed Indians in incest trials linked this sector of the population to this particular crime. Indian actors, for their part, both contradicted and reinforced such representations, which were largely intended to lessen culpability. Indeed, Indians were well aware of the stereotypes Spaniards held about them, and they were able to "appropriate the language of the dominant" (Kulick 1996) for their own ends when on trial. Such generalizations had polarizing effects, which not only legitimated the marginalization of Indians in the minds of Spaniards, but also worked against those who denounced Indian offenders before the Spanish courts. Indian women and girls would have been at a particular disadvantage, considering the gendered nature of incestuous violence in colonial Guatemala.

Obviously, power imbalances will characterize any courtroom situation, and these discrepancies can have impacts outside of it. Following Sally Engle Merry (1991), the processing of cases in courts is one way in which the culture of a dominant group is introduced to a subordinate one. She described such instances as "cultural performances" that create change in sociocultural practices and consciousness (Merry 1991, 892; see also Merry 1994). This is not to say that such introductions lead to a one-to-one cultural transfer in favor of the dominant group. In Susan Kellogg's terms (1995, xxii), law is "an arena of cultural conflict and accommodation" and "a catalyst of cultural change and adaptation." The criminal process in colonial Guatemala would have clarified to incestuous offenders who acted in good faith that their sexual activity was inappropriate from the court's perspective, shaping perceptions of incest and relatedness in the process. It would have shown those who knowingly committed incest the potential legal consequences of such 
actions, perhaps mounting pressure for future compliance. Some individuals no doubt obliged warnings by magistrates to separate from their sexual partners, but others were tried more than once (Case 17). And, since word of incest trials could spread and punishments could be public, enforcement of incest law (or lack thereof) would have made an impression on other community members as well. To be sure, incest trials triggered conversation and debate about the nature of kinship and incest, which could serve to either reinforce incest law or pave the way for new possibilities.

Use of colonial criminal records for historical reconstruction has both its limitations and its benefits. Factors like power disparities between authorities and witnesses, imperfect translations of non-Spanish-speaking individuals, and the handwritten method of recording and typical third-person rendering of oral testimony have all had the potential to impact what was said during a trial and included in the final written product. ${ }^{11}$ At the same time, these documents offer information on individuals who would otherwise be lost to history, sometimes even providing the reader with direct quotes from witnesses or personal letters of accused persons.

Also, though it might be tempting to classify criminals as social outliers, scholars have cautioned against this. For example, Steve J. Stern $(1995,52)$ found that in colonial Mexico, "episodes of criminal violence represented not so much a rupture that stood apart from normal social dynamics but an excess committed within a recognizable logic of behavior." Richard Boyer (1989) also spoke in terms of "excess," noting how married individuals (particularly women) might be forced to act once marital ideals of reciprocity became too overshadowed by a spouse's mistreatment, whether it came in the form of physical violence, neglect, or otherwise. Guatemalan incest cases likewise reveal behavior that crossed into the realm of the excessive, especially in the figure of the father-offender. In essence, deviant behavior can provide insight into cultural norms despite breaching their limits.

Needless to say, participants in incest trials often contradicted one another. While it remains impossible to fully comprehend what transpired between them-if anything-the arguments they made are still informative. To summarize Marilyn Strathern (2005, 50-1), the cultural resources individuals use in support of a persuasive point must communicate something that is possible, and possible worlds inform actions in the present one. Thus, regardless of whether the statements made in incest trials were accurate, exaggerated, or outright false, they were not completely divorced from the realm of cultural possibility that seeped into the lives of colonial actors.

The criminal records analyzed here are housed at the Archivo General de Centro América (AGCA) in Guatemala City, which I visited during the summers of 2012, 2014, and 2015. Using the archive's fichero 


\section{Introduction}

(card catalog) as a guide, I was able to locate, and then photograph, the documents for this study. During my time at the archive, I consulted drawers 1-2 through 1-23,1-25,1-28, and 1-29 in the section of the fichero dedicated to civil and criminal records, which is organized chronologically. I later analyzed the digital versions of the documents using a combination of qualitative and quantitative analyses.

Seventy-three of the cases found addressed incest-or what would theoretically constitute incest-as the sole crime or as one of multiple crimes. These cases make up the Incest Case Log located in the Appendix and are cited as Cases 1 through 73 in the main text. Other court records that contained information pertinent to this analysis also appear in the text and are cited accordingly. All of these records stemmed from the Spanish secular courts, and the majority of incest cases were explicitly identified as criminal cases. Criminal proceedings-in contrast to civil proceedings-dealt with offenses that entered the public sphere and had a perceived negative effect on the community (Cutter 1995, 111-3).

Over half of the incest cases were tried in the jurisdictional area of Sacatepéquez, which contained the capitals of Antigua Guatemala (or Santiago de Guatemala) and Nueva Guatemala (modern-day Guatemala City). ${ }^{12}$ Incest trials typically involved (illiterate) non-elites, making them especially valuable for the study of subaltern lives. Only 11 out of 164 individuals carried the honorific title of don or doña. ${ }^{13}$ One Indian man was listed as a principal, an esteemed status in indigenous communities (Case 21). Indians accounted for forty-six of the actors in incest trials, individuals of mixed descent for thirty-two, and Spaniards for eight. ${ }^{14}$ Seventy-eight individuals did not have their race recorded in line with Christopher Lutz's $(1994,103)$ observation of a growing tendency for race to go unrecorded in notarial records from the late colonial period. Significantly, in contrast to their relatively small representation among defendants in incest trials, ethnic Spanish men dominated positions of power in the Spanish secular courts in Guatemala and throughout the Americas. This was also true of the clergy, members of which regularly featured in incest cases in one way or another.

In colonial Guatemalan incest trials, the words amancebamiento ("concubinage"), concubinato ("concubinage"), and ilícita amistad ("illicit friendship") were frequently used interchangeably. ${ }^{15}$ Their main significance here is that they connoted nonmarital (sexual) unions between men and women. As noted above, such unions could take the form of sexual violence. Though modern notions of rape as sexual intercourse with a person without their consent or against their will were relatively absent from colonial jurisprudence (see Komisaruk 2008, 373), the issues of force and consent did arise in some incest trials. This study considered sexual unions to be incestuous rape when there was a clear articulation at some point during the proceedings that a woman or girl 
was either physically assaulted or otherwise compelled to succumb to a male perpetrator. Though verbs like estuprar ("to deflower") and violar ("to rape") theoretically connoted forcible sexual relations, in Guatemalan incest cases these verbs (and their linguistic variants) were most consistently used in reference to a loss of virginity and were not a reliable indicator of coercive sexual relations. Verbs like forzar ("to force" or "to rape") and violentar ("to force"), on the other hand, were explicitly juxtaposed to consensual sexual relations (e.g. Case 65). ${ }^{16}$

Overall, incestuous crime was associated with force or intimidation approximately 27 percent of the time, though this is surely an underrepresentation of the reality of sexual coercion within incestuous relations. Surviving court records are often incomplete, sometimes providing little more than a name of an individual and the crime of which they were accused. Further, the question of consent is rarely simple, and power asymmetries based on factors like gender and generation could have in fact contributed to sexual coercion even when violence or fear was not expressly articulated. The approximate ages of participants in incestuous crime are included in the Incest Case Log, provided that they were available. However, it should be noted that children in colonial Latin America could be attributed sexual agency at a very young age by modern standards. Bianca Premo $(2005,120)$, for instance, found that girls in colonial Lima were generally considered sexual innocents when they were around eight years of age or younger. As they grew older, the state of their sexual honor became more suspect.

Certain stylistic choices have been made for the sake of consistency and readability. Spanish names and terms appear in their modernized forms in the main text. Indigenous surnames, on the other hand, reflect their colonial spellings because they have largely been preserved out of concern over the legal consequences, particularly with respect to land titles. Also, notaries rarely spelled them consistently, and alternative spellings are included in the endnotes when appropriate. Translated passages follow modern conventions for punctuation and the capitalization of words. I have omitted some words and phrases from translations because they are burdensome to the reader. For example, criminal records are full of qualifiers like "aforementioned" and "said" (e.g. "the aforementioned María"). In translations, this phrase would be simplified to "María." I have also replaced identifiers like "the declarant" or "she who states" with pronouns or a referent's name for the same purpose. On occasion, a referent's name has been inserted into a quoted passage for the sake of clarity. Brackets designate these types of modifications. The original Spanish of translated passages can be found in the endnotes with any available folio numbers and more specific document identification when necessary (some cases in the Incest Case Log spanned multiple documents). 


\section{Introduction}

It should also be mentioned that once an actor from a criminal case has been identified by their full name in the main text, they are thenceforward referred to by their first (and/or middle) name only. First names communicate gender identity, a helpful reference point in cases that center around interactions between men and women. Further, being that incest cases dealt with families, various actors could share a surname, making first names more useful for conveying individual identities. Defense counsel are referred to by their surnames once introduced because they were always male and fell outside the principal narrative of the case.

\section{Overview of Chapters}

Chapters 2 and 3 set the stage for understanding social relations and incestuous crime in colonial Guatemala. Chapter 2 examines the intersection of incest with two major elements influencing social relations in Spanish America-the system of socioracial categorization and the culture of honor (status or virtue). Chapter 3 further contextualizes incestuous crime through exploration of legal and cultural precedents, jurisdictional issues, and the criminal process, including the special treatment afforded Indian actors in the legal realm. It ends with a discussion of the typical penalties for incestuous crime in colonial Guatemala and their correlations with race, gender, and marital status.

Chapters 4 and 5 discuss broad patterns within incestuous crime and relatedness in colonial Guatemala. Chapter 4 first considers debate among legal professionals regarding whether certain forms of incest were more criminal than others and the types of incest that were typically brought to formal trial. It then examines the ways in which the nature of kin ties could contribute to incestuous crime and factor into various aspects of the criminal process. Chapter 5 illustrates how incest codes came into conflict with the malleable nature of kinship practice in colonial Guatemala. It also demonstrates the ways colonial actors of diverse backgrounds were able to take advantage of kinship and incest as they dealt with (forced) sexual relations, marriage, and conflicts with authority figures.

Chapter 6 focuses on a particular segment of colonial society-the Guatemalan indigenous population. It discusses the intersection of colonial constructions of Indianness, particularly its ignorance aspect, with incestuous crime. It examines strategic usage of the ignorance defense in incest trials and its potential implications. It also demonstrates the ways in which challenges to Indianness were ignored, leaving little room for counternarratives. Chapter 7 summarizes the findings of this study and proposes possible avenues for future research. 


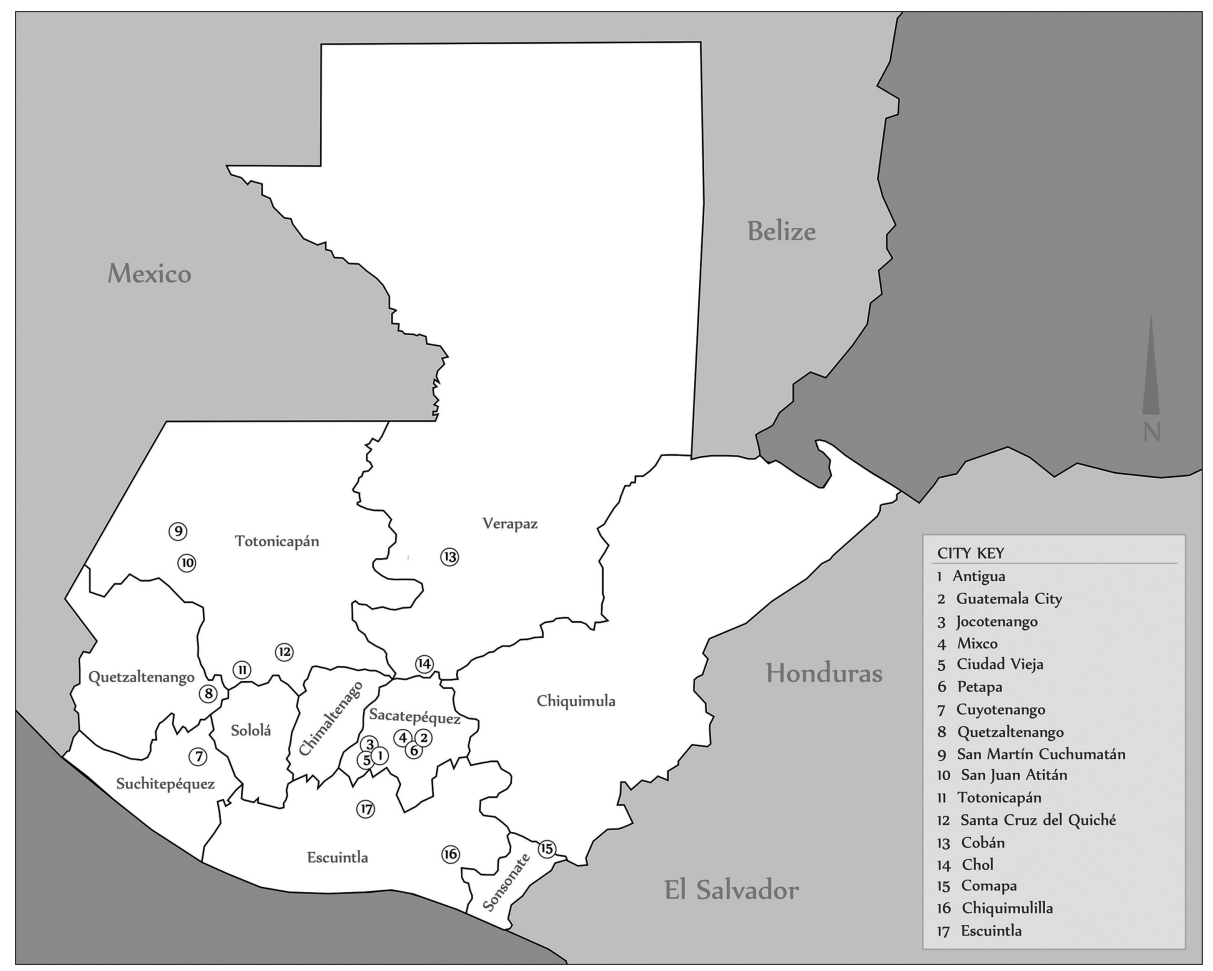

Figure 1.1 Modern Guatemala overlain with late colonial jurisdictional divisions (1785-1821). Jurisdictional information adapted from Komisaruk (2013, xv). Map by Zachary S. Klukkert.

\section{Notes}

1 Case 61.

2 Rosalía's surname was also written as Surquiah, Surcheah, Surchiah, Surquial, Zurquig, Surchah, Suchiah, Suaquial, and Sequeh.

3 Carsten $(2001,50)$ cautioned against drawing stark lines of contrast between Western and non-Western categories. Thus, "Western" is used here as a way to highlight that not all worldviews are influenced by Judeo-Christian values and/or emphasis on the modern scientific method rather than as a way to distinguish between homogenous Western and homogenous non-Western conceptual frameworks.

4 Descendants of indigenous Central Mexican populations also resided in Guatemala. For example, Ciudad Vieja was a community of largely Tlaxcalan ancestry (Komisaruk 2013, 62).

5 For example, Margadant (2001), Rodríguez-Sáenz (2005), Jaffary (2007), and Penyak (2016). Incest cases also surfaced in Castañeda's (1989) treatment of sexual violence and estupro (loss of virginity) in Nueva Galicia. The corpus of colonial Guatemalan rape records analyzed by Komisaruk (2008) 


\section{Introduction}

also apparently included some incest trials. Guatemalan incest trials are also treated in Saffa (2019).

6 See, for example, Lévi-Strauss (1969) and Goody (1956).

7 In the contributions to Carsten (2000b), the term "relatedness" was adopted and used alongside, or in opposition to, "kinship" to indicate a willingness to embrace indigenous idioms of being related (Carsten 2000a, 4). Here, the term is used interchangeably with "kinship" as a reflection of changes in kinship theory following postmodern critiques.

8 See, especially, Schneider (1984). See also Collier and Yanagisako (1987).

9 See, for example, Weston (1991, 1995), Carsten (2004), and the contributions to Franklin and McKinnon (2001), including Weston (2001), Howell (2001), and Yan (2001). Franklin (2013) showed how biology itself is relativized in the context of in vitro fertilization (IVF).

10 See Ortner (1972), Rosaldo (1974), and Rubin (1975) for early discussion of this topic.

11 For extended discussion of issues related to text production and archives, see, for example, Burns (2010) and Tortorici (2018).

12 The capital moved to Nueva Guatemala following extensive damage to Antigua Guatemala caused by an earthquake in 1773 .

13 This title theoretically originated in legitimate descent from high-status parents (Twinam 1999, 4).

14 Domingo Mariano Mejía (Case 46) was identified as both Indian and mestizo (of Spanish and Indian descent), but because the Indian identification surfaced more emphatically in the case, it was favored here. Also, doña Teodora Bocanegra (Case 45) was considered Spanish in this study since her title and the identification of her sister as Spanish would have surely resulted in her treatment as such. All information related to racial identification can be found in the Appendix.

15 See Komisaruk $(2013,207)$ for further discussion of such terms in late colonial Guatemala.

16 For further discussion of rape, deflowerment, and associated terminology, see, for example, Castañeda (1989), Lipsett-Rivera (1997), Komisaruk (2008), and Tortorici (2015).

1 See van Deusen (2015) for a discussion of the breadth of people to whom the term indio could refer.

2 Though use of the terms casta and calidad to refer to this system has been found anachronistic or inappropriate for early Spanish America, they are relevant for the seventeenth and eighteenth centuries (see Schwaller 2016). In late colonial Guatemalan criminal records, when individuals were asked to provide their calidad, they responded with a socioracial term, making calidad the most appropriate terminology for the study at hand.

3 Information regarding the system of two-republics can be found in Borah (1983), Lutz (1994), and Schwaller (2016). See Hill, II (2002, 124-7) for a discussion of the Indian cabildo as a barrier/broker institution and Hill, II (2012) for an analysis of how Indian aristocrats utilized the introduced cabildo to maintain their status.

4 The enslavement of women and children under the age of fourteen was outlawed in 1534 (van Deusen 2015, 8), and women were declared exempt from tribute payments in 1756 (Hill, II and Monaghan 1987, 57). For a history of religious colonialism in Guatemala, see van Oss (1986). Sherman (1979) provides a comprehensive treatment of forced native labor in Central America. Information on the laborio and non-Indian tribute can be found in Lokken (2001) and Milton and Vinson, III (2002). 
5 It was not until after Independence that Guatemala became conceptually divided between ladinos and indios, the former being associated with Western values and some degree of Spanish heritage, while the latter was viewed as racially and culturally distinctive (Taracena Arriola 1982, 99-100). This division was characterized by prejudicial notions of Indian inferiority, which has continued to have an impact on race relations in Guatemala to this day (see, for example, Hale 2006).

6 ...la poca union que guardan entre si Yndios, y Ladinos... AGCA A1.15 Leg. 5426 Exp. 46305.

7 Bernardo's surname was also spelled Cuachita, Quachito, and Cuachito.

8 ...la muger q.e se mescla con otro q.e no sea de los de su casta p.r la mas perdida, y despreciable...f. 14.

9 Notably, in 1803 royal officials determined that subsequent marriage between relatives who had produced incestuous offspring was sufficient to legitimate them (Gacto Fernández 1969, 104 in Twinam 1999, 130).

10 Works that discuss the culture of honor include Socolow (1980), Stern (1995), and the various contributions to Johnson and Lipsett-Rivera (1998b).

11 For discussion of the impact of colonialism on indigenous women's status, see Clendinnen (1982), Kellogg (1995), Restall (1997), and the various contributions to Schroeder et al. (1997). Works that consider social organization and descent reckoning include McCaa (2003) for the Nahua, Restall (1997) for the Yucatec Maya, and Sanchiz Ochoa (1980), Luján Muñoz (1983), and Hill, II $(2002,2012)$ for the Guatemalan region. Comments on adultery include Sanchiz Ochoa $(1980,190)$ and Terraciano $(1998,724$, 729-30). Burkhart $(2001,92)$ mentioned that stoning, which many sources claim was the pre-Hispanic punishment for adultery, is found in the Bible as well. She also provided general commentary on the potential problems of using colonial texts to reconstruct pre-Hispanic cultural norms.

12 The relationship between Andrés Victorio and María Anastacia Vásquez was only counted once here, even though they were tried in 1794 and 1797 (Case 17).

13 Relationship types reflect accusations or the type of relationship being scrutinized.

14 ...los primeros obsequios, y servicios de sus hijos, que le son debidos por naturaleza... ACGA A1.15 Leg. 5475 Exp. 47050 f. 12v.

15 Cases 11, 29, 33, 45, 48, and 59.

16 Scandal and magic were the other two weapons discussed by Stern (1995, 108-10).

17 The nature of the relationship between Narciso and Gregoria would be contested later in the trial with the claim that Narciso and his wife had raised Gregoria but were not her (biological) parents. This issue will be discussed in Chapter 5.

18 See Schwaller (2011) for a description of the various roles within the ecclesiastical bureaucracy. The provisor was the chief administrative officer of a New World diocese under the bishop. The provisor was often also the vicar-general, the superior ecclesiastical judge of a diocese and chief administrative officer under the bishop (Schwaller 2011, 78, 279).

19 Si decis algo me ajondás pues me meten en la carcel y á vós en la Casa Nueva. AGCA A1 Leg. 2959 Exp. 27997 f. 3v.

20 See Schwartzkopf $(2013,740)$ for a discussion of the evolving role of comisionados. In the late colonial period, these individuals lived in largely indigenous communities and were sources of information and surveillance for the alcalde mayor. 
21 ...q.e abia pecado con su dha hija por tener que sentir de su muger, pues sabia que tenia ilicito comercio con el declarante, con José y Man.l de Pinula, y otros que no se acuerda; y q.e lo podia acreditar. AGCA A1 Leg. 2959 Exp. 27997 f. $6 \mathrm{v}$.

22 ...no fue porq.e hubiera sido verdad q.e habia cometido tal pecado sino apacionado de lo q.e le habian contado de la ilicita amis[tad de]l Comisario y su muger. f. 9.

23 ...el mas orrendo crimen y p.a apoyarlo sugerir a la hija a q.e bulnerase el honor de su Padre, que es hasta donde puede llegar la malicia. f. 15.

24 ...á escondidas de su Padre por el temor q.e le tiene á este la Madre de la Confesante por q.e es muy bravo, y luego la golpea. AGCA A2.2 Leg. 237 Exp. 5068 f. 24.

25 ...haviendo tenido q.e ver con esta Manuel Cornel, y despues con la muger del q.e declara Maria Manuela Lopes; en venganza se enredó el con la referida su hija María Leandra, y q.e por esto lo puso preso el citado Jues. f. 6v.

26 ...haviendosele imputado por este q.e el q.e declara tenia ilicita Amistad con Maria Leandra Amperes su hija, no siendo asi, le dio corage, y lo hiso de veras... f. 8 .

27 ...en venganza de lo q.e Amperes hiso con su muger, se empeño en perseguir á la de Amperes, y como no pudó conseguir su intento, y la muger del q.e habla lo trascendio, acordandose de lo q.e havia hecho con ella Amperes, trató de persuader á la muger de este á q.e pecase con el q.e declara, y q.e ultimamente lo consiguio, y por su medio tubo q.e ver ilicitamente con Maria Manuela Lopes...como unas ocho ocasiones. f. 8v.

28 ...picada de q.e haviendo tenido q.e ver Josef Silverio Amperes con la q.e declara, se lo dijo el mismo á su Marido, con q.n por esto, y por haver la pillado en el acto con Amperes paso trabajos. f. 14-v.

29 ...quiso aquel matar á este, por cuya causa el referido su marido la daba mala vida: q.e por q.e este se sosegara, y por vengarse cometio este pecado, no estando impuesta en la gravedad... f. $18 \mathrm{v}$.

30 See, for example, Rojas Flores $(2007,116)$. See also Case 15, where the defendant attributed the accusation of incest with his daughter to the crazy jealousies of his wife.

31 See Socolow (1980, 46, 51-2), Premo (2005, 125), and Komisaruk (2013, 238).

32 ...que de miedo de lo mucho q temio la avia de castigar. f. $3 \mathrm{v}$.

33 See Francisco de Solano (1969) for linguistic areas in late colonial Guatemala.

34 ...si tu suegro quisiere asotarme me defendereis... f. 3v.

35 However, her mother-in-law denied having said this in her own testimony.

36 Yo soy hija solo vengo á ver como haz am[aneci]do...

37 ...quiso aun darle fuego á la casa hablando desatinos.

38 ...juzgando mal de su suegro, y desesperada entre otros desatinos que iba á executar como que estaba fuera de si, tomó un machete del campo, y se hirio con el la garganta con animo de matarse...

39 ...la habló con amor diciendola que el era que avia ido á ver como avia amanedido...

40 See Ochoa Sanchiz $(1980,190)$ regarding reports of indigenous women who ran away to the wilderness to prevent Spaniards from forcing them to commit adultery. 
1 Following Jack Goody $(1983,136)$, the Church had used two systems for determining degrees of consanguinity - the Roman and the Germanic-with a formal shift to the Germanic system in the eleventh century. The Roman system counted degrees by the number of acts of generation between two individuals such that an uncle and niece, for example, were related in the third degree. That is, ego to ego's parent equaled one degree, ego's parent to ego's grandparent equaled one degree, and ego's grandparent to ego's uncle equaled one degree, totaling three degrees. In the Germanic system, sibling groups formed a generation, and degrees were counted by determining the number of generations from a common ancestor. In this system, an uncle and niece would be related in the second degree.

2 ...yaciendo á sabiendas con su parienta, ó con parienta de su muger ó de otra con quien hobiese yacido fasta el quarto grado... This is in accordance with the dictates of the Fourth Lateran Council of 1215, which narrowed incest prohibitions from the seventh to the fourth canonical degree of consanguinity and affinity.

3 Compadradgo (or compadrazgo) would come to refer specifically to the connection between a godparent and the parents of a child. See Diccionario de Autoridades (1726-1739 v. 2). This text defines this term in the context of baptism, though presumably it would also apply to confirmation.

4 Spouses of spiritual parents were also included in this category, at least for the rite of baptism.

5 ...tan mancebos que non podiesen mantener castidat....

6 It is unclear from the wording whether a woman would also be put to death for committing incest or whether she would be subject to the penalty for adultery specific to women.

7 Only one person was to act as a sponsor for baptism. At most, one man and one woman were permitted. The number of sponsors was not specified for confirmation. However, it was spoken of in the singular.

8 Following the Diccionario de Autoridades (1726-1739 v. 2), cuñado(a) referred to any relative through affinity regardless of degree. However, its authors noted that in contemporary common usage it denoted a husband or wife of a sibling or the brother or sister of one's spouse.

9 Cópula o accesso carnal con parienta por consanguinidad o afinidad.

10 ...grados de parentesco, de conSaguinidad, y aFinidad, y compadrazgo.... Newberry Library Ayer MS 1508, 147v-8.

11 A sus hijos e hijas los llamaban siempre por el nombre del padre y de la madre...de esta manera, el hijo de Chel y Chan llamaban Nachanchel, que quiere decir hijos de fulanos y esta es la causa...dicen los indios que los de un nombre son deudos y se tratan por tales...Y asi ninguna mujer $u$ hombre se casaba con otro del mismo nombre porque en ellos era gran infamia.

12 ...parentesco, así carnal como espiritual de la abuela, de parte de la madre....

13 See also Fuentes y Guzmán ([1690] 1882 v. 11, 32).

14 The responsibilities of a fiscal included ensuring that all residents attended Mass, teaching children the catechism, and recording matters such as the rite of baptism (Burkhart and Gasco 2007, 212). See, for example, Case 1. This type of fiscal differed from the crown attorney referred to by the same title.

15 ...no era bien fuese co[n] Una criatura en los brazos... f. $1 \mathrm{v}-2$.

16 Oidores were judges with civil and criminal functions in Guatemala and other non-viceregal audiencias.

17 Parcialidad was the Spanish term for a pre-Hispanic Maya unit of social organization, several of which might have technically fallen under the jurisdiction of a colonial town. 
18 ...siguiendo las huellas del Apostol que los que publicam.te pecan, publicam.te sean corregidos... determiné darle a dho insestuoso publico sincuenta asotes publicos, y siendo requerido para dha penitencia clamó disiendo que pedia no lo desonrrasen y que ofrecia la penitencia pecuniaria de sien para que se aplicasen a esta Yglec.a y Juntam.te prometiendo emmienda... f. 1, f. $20 \mathrm{v}$.

19 ...siendo tan facil, especialm.te á los Curas, imponerles por qualquier delito pena de asotes, y despues con titulo de piedad, compensarla en dinero, obligandolos á esta con amenaza... f. 12.

20 The ius commune tradition generally refers to a culture of legal thought formed by a combination of canon and Roman law.

21 In fact, in Case 22, the magistrate explicitly stated that Eusebia Escalante's sentence of reclusion stemmed from perjury.

22 Penalty information was taken from records of 167 individuals in which Josef Silverio Ampérez (Case 65), Andrés Victorio (Case 17), and María Anastacia Vásquez (Case 17) were counted twice because they were each tried on two separate occasions. Punishments such as spiritual exercises, the habilitation of marriage, or court fees were not included as major penalties in the quantitative data. However, all penalty information, including these minor sentences, can be found in the Incest Case Log in the Appendix.

23 If a cease of communication was ordered of one party, all parties whom the order would affect were included in the total number of those subjected to this penalty.

1 Similar to Buffington's (2000, xi) use of the term "criminality," its use here is intended to highlight the constructed nature of criminal matters.

2 ...la diferencia, y maior gravedad de la copula nefaria, entre padre, é hija, comparada con la de incesto en general... AGCA A1.15 Leg. 4381 Exp. 35730 .

3 ...no digo entre Madre, e hijo, pero entre tia, y sobrino, ó entre primos, causa natural horror el co[i]to inhonesto, se resiste por si enteram.te a la naturaleza por desvocada que sea, y con mucho mayor Razon se resiste el dar excensia al que se imputa a mi p.te por ser su Madre de sessenta años; $y$ por q.e no era posible que de un golpe huvieran vensido esta natural resist.a y casual, por Razon de la hedad; havia p.a ello precisam.te de haver precedido continuaz.n de acciones cariñosas, con que aunq.e con mucha dificultad tal vez, se Huviera Ydo vensiendo el natural horror, pero nada delito ha precedido...

4 See, for example, McKinnon (1995) on scientific discourse and Archibald (2001) on classical and medieval literature.

5 See, for example, Fox $(1980,48)$.

6 ...el delito de que tratan es atroz, y lo es en tanto grado, q.e ni por dro. Canonico, ni Civil, se encuentra texto expreso que trate (en materia de incestos y sus penas) del executado entre el Padre y la hija; delito verdaderam. te q.e ni aun se presume, y su repugnancia nos quedó detallada desde la ley escrita; y aun Seneca el mayor, siendo Gentil, quando á otro proposito tocó p.r insidencia la deformidad del coito habido entre los Parientes ó deudos immediatos, lo calificó por criminal criminalisimo; y efectivam.te p.r dro. comun, los reos deste delito eran castigados con pena de muerte, haviendo fuerza, como p.r exemplo, el acceso con la entenada, Madrasta, sobrina, o.a con q.e siendo de Sup.r gravedad el que se dice haver tenido Patricio de Leon con su tierna hija Fran.ca no havia otra cosa q.e hazer, sino p.r el merito de la causa mandarlo ahorcar... AGCA A1.15 Leg. 3028 Exp. 29261 f. $9 \mathrm{v}-10$.

7 ...el incesto q.e cometio no es de los mas áborrecidos, y que castigan con mas severidad las Leyes, por que la Muchacha no es su Parienta por consanguinidad, sino por áfinidad. f. $5 \mathrm{v}$. 
7 ...el incesto q.e cometio no es de los mas áborrecidos, y que castigan con mas severidad las Leyes, por que la Muchacha no es su Parienta por consanguinidad, sino por áfinidad. f. $5 \mathrm{v}$.

8 Note that incidents of incest outnumber incest cases because some cases included multiple accusations of incest.

9 These percentages derive from penalty data that was limited to individuals charged with single (as opposed to multiple) incestuous relationships/incidents and whose sentences were recorded.

10 These percentages come from data on eighty-nine two-person relationships where affinity and consanguinity could be determined. (Eight others did not have the relevant relationship information.) Three-party incest cases were broken into two data records (e.g. man/sister 1 of 2 , man/sister 2 of 2 ).

11 ...mediante á que el parentesco, que entre los dos mediaba, provenia de copula ilicita...

12 ...el hallarse desnudos en un mismo lecho los parientes no funda presuncion, ni prueba de copula entre ellos; p.r q.e aunq.e bastaria respecto de los estraños, tienen los parientes a su favor mas fuerte y vehemente presuncion de honestidad, nascida del mismo parentesco. AGCA A2.2 Leg. 205 Exp. 4188 f. $32 \mathrm{v}$.

13 ...el hallarse los consanguineos desnudos en un mismo lecho prueba suficientem.te el insesto: pero tambien dice q.e debe entenderse quando estos parientes colaterales yacieren en el lecho secreta, y ocultam.te, y no en publico, p.r q.e en este caso no bastaria semejante prueba. AGCA A2.2 Leg. 205 Exp. 4188 f. 33.

14 Collins cited a bound volume of cabildo records related to the management of the community fund of Jacaltenango dated from 1627 to 1756.

15 ...los vicios dominantes son la embriaguez y lascivia, abandonándose a incestos horribles entre padres y hijos...siendo el riesgo próximo el dormir todos juntos.

16 ...en una propria cama, vajo de una misma cubierta con la referida su Madre, y si por parte de esta á experimentado alguna [vez], accion, ó cariño especial q.e denote algun requerimiento torpe...

17 ...desde pequeña ó desde q.e le entro la razon le puso su Madre cama separada de suerte q.e nunca se sirbio de la de su Padre aunque estaban en una misma piesa... AGCA A2.2 Leg. 199 Exp. 4085 f. 9v-10.

18 Miguel's surname was also written as Cayxon, Caxon, Caison, Cayson, Caychon, and Cahxon.

19 Antonia's surname was also written as Chacal, Chabalan, and Zic.

20 ...nunca, en ningun tiempo, ni por mal pensamiento ha tenido con la referida su Madre el mas leve descomedimiento sobre el particular, pues á mas de ser Muger mayor, siempre le ha guardado el respeto devido de Madre...

21 ...accion alguna que indique maldad pues Cantarillas trata a la Agustina con el respeto de cuñada durmiendo cada uno en su cama y solo si se resiven a la hora de comer y beber...y quando murio la muger de aquel le dejó encargado a la Agustina su hermana q. cuidase á su marido lo mismo que ella...

22 ...poseida de miedo, terror, y respeto, á sus riñas y amenasas... f. 4v.

23 ...remediasse su desgracia, pues se condenaba, y contra su voluntad se hiba al infierno... f. 4v.

24 ...valiendose de los halagos de Padre y de la inocencia de la exponente, la primera vez tubo polucion con ella, esto es, q.e usaba de sus piernas, y lo externo del utero p. a la confricacion, y poluccion... f. 6.

$25 . . . y$ aunque extorta le entregó su cuerpo, fue poseida del terror, y del respeto... f. $6 \mathrm{v}$.

26 ...pero ningo. consumó intra vas. p.r q.e tenia particular estudio, en la extravasacion... f. $6 \mathrm{v}$.

27 ...no teniendo mas livertad q.e ella ni mejores alcancez, queria remediarlo con disimulos y con las quejas... f. $7 \mathrm{v}$. 
28 ...como ella hera muchacha y le tenia un respeto reberencial spre. le obedecia en cuanto le mandaba saliendo con el fuera de la casa á biajes y a su Labor, y q.e spre. q.e estaban solos, el la acariciaba atribuiendo ella estos cariños á un amor onesto, hasta q.e el poco, á poco se fué exediendo con ella en las ocaciones á proposito sin mediar palabras ni conosim.to y q.e cuando hubo lugar a la refleccion yá Felipe Gil havia consumado el acto con ella: q.e la q.e declara no tenia trato con ning. a otra persona mas q.e con el, y spre. sedia aunq.e con repugnancia p.r no atreberse á desirle q.e no... f. 9v.

See Premo $(2005,61-8)$ for a discussion of the concept of "reverential fear" and debate about who had the capacity to inspire it.

29 Again, Cases 17 and 65 were broken into 17a/17b and 65a/65b.

30 Sometimes multiple plaintiffs who did not share a gender came forward to make an accusation. Thus, each plaintiff was considered individually in these tallies.

31 ...p.r ser cristiano, y desseoso de la honrra de Dios...

32 ....solo el poder abitar con el lisitamente si se le dispensaba... f. 5.

33 ...me rogaban no se supe ese nunca su delacion por el cruel castigo q.e experimentarian. f. $1 \mathrm{v}$.

34 ...el motibo q.e tuvo p.a denunsiar á su P.e siendo sobre la tierra los P.es las personas a qus mas reverensia y amor deben los hijos? f. 5 .

35 ...los hijos son cuerbos p.a sacar los ojos y que conforme a dro No deben tirar contra su Padre sino en cassos capitales por el capitulo Quarto del Decalogo Que hassi lo manda... f. 6v.

36 ...por amor de Dios que le buscase una casa donde servir por que no queria estar con su Padre...

37 ...lo estraño que es, el q.e un hijo acuse á su Padre... f. 12.

38 ...como viese q. su P.e Jose M. a huviese echado sobre si un crimen q. no habia cometido, esta por no desmentirle, ignorando lo q. hasia, manifestó su convencimiento... f. $14 \mathrm{v}$.

39 ...pues su propria hermana Juana Josefa la acusa, que esta no há sido apremiada, ni obligada para que los denunciase... f. 5.

40 ...es mentirosa su hermana, y tal ves la han aconsejado. f. 5.

41 ...pues no pueden ser zelos solamente pues de su hermana; sino motivos positivos los que le asisten para querellarse de su ilicito comericio con su marido... f. $16 \mathrm{v}$.

42 ...siento q.e mi hermanita esté creciendo p.r q.e no viese el mal ejemplo de mi Padre. f. $5 \mathrm{v}-6$.

43 ...la sujestion de la tia no es creible que hiciese en la petrona maior imprecion que la natural de un[a] hija á un Padre para caluniarlo dijo que no es de estrañar el que se dejara la muchacha llevar del concejo de la tia quando esta le ha impuesto de que no es su hija. f. $11 \mathrm{v}$.

44 Ella no se hubiera atrevido á semejante desacato, si su tia Antonia no la hubiera sugerido á la desovediencia manifesta[n]dola que no era hija suya. f. 20 .

45 ...no soy casado ni tengo bijos ningunos p.r que una muger q. tuve en mi compania esta me estubo cuidando p.r algun tpo. $y$ asi q. se aburrio de cuidarme se mud[ó] y se yevó a sus hijos... una muchacha q. aparese acriminandome de unos tan enormes delitos, q.e esta es hija de la muger q. me cuidó, y se yama Maria Jososefa [sic] la q. no es hija mia p.r q. si lo fuera no tirara tan desenfrenadam.te en contra de su padre...si fuera su padre como eya dise le tirara la sangre a bolber p.r su padre viendolo en la calamidad q. se halla, y preso con tan grandes crimenes de q. lo acusa, y asi doy p.r nula su declarasion falza, y esta se tiene p.r hija de la dh. a Micaela, y no lo es p.r q si lo fuera no procurara ni ubiera procurado desunir a su padre del lado de su madre sabiendo q. eran casados luego no es hija sino pepe...

The term pepe is discussed further in the following chapter. 
46 Don Juan Manuel would later deny authorship of this text.

47 ...me he enterado de que dha Secilia no es parienta por ningun termino en sanginidad mia... f. 21.

48 ...se hapellidan Mangoches, y estas me tratab.n de pariente, Yo con la Ygnorancia dha por tal las conocia = Por lo que es, que la dha Secilia dise ser mi Marido quien la deve su onór, sin embargo de ser falso... f. 21-v.

49 ...no es presumible que esta se abanderize mas á la que confiesa que á su misma hija. f. $6 \mathrm{v}$.

50 ...en el concepto legal siempre se presume q.e el padre quiere favorecer la causa de su hijo. f. 18.

51 Hipólito’s surname was also written as Cojulun, Cojulún, Coxulum, Coxulun, Cujulun, Cujulum, and Cuhulum.

52 ...tanto por su sexo y calidad, quanto por que siendo la muger propia, no puede descubrirse con que intension, y quales antecedentes la compelerian á deponer contra su marido un testimonio tan escandaloso... f. $34 \mathrm{v}-5$.

53 ... si huviera cometido tales exesos como hombre lo confesara...quando á su hija le levantó este testimonio como no se lo ha de levantar al confesante. f. 18.

54 ...y como sobrino de la muger del declarante se valieron de la ocasion para formarle esta calumnia al confesante. f. 18.

1 An earlier version of this chapter appeared in Saffa, Sarah N. "She Was What They Call a "Pepe": Kinship Practice and Incest Codes in Late Colonial Guatemala.” Journal of Family History 44 (2): 181-99. Copyright (C) 2018 (Sarah N. Saffa). DOI: 10.1177/0363199018818617.

2 ...á el Padre de la muchacha le crio de Pepe, p.r cuyo motivo las criaturas le intitulan de abuela.

3 ...p.r la causa de haverla cricido, le disse Prima pero q.e no hay ningun parentesco.

4 ...es hija de Ana Albarado y q.e esta la hubo antes de su primer matrim.o con Benito Berriondo quien trataba á esta muchacha con el cariño de una buerfana recojida, q.e algunos en el Pueblo creian ser hija de Benito y de Ana, otros q.e de esta solam.te y algunos q.e ni de uno ni de otro, sino q.e hera lo q.e llaman Pepe... f. 8v.

5 ...pepe ó muchacha á quien su muger Ana Albarado havia recojido en su casa p.r caridad p.a criarla... f. 12.

6 ...p.r su ignorancia y haver creido q.e hera muchacha á q.n su muger havia criado p.r huerfana ú otro motibo de caridad. f. 12v.

7 ...por el respecto q tenia a su Madre Magdalena de Estrada y mied[o] grande a su tia Maria Phelipa permitio q esta su dha tia diera la criatura Gregoria Antonia hija suia a los dichos Narciso Gonzales y Petrona Quintanilla, su muger para q de charidad la crian. f. $17 \mathrm{v}$.

8 ...Yo y dho Narciso mi marido, somos sus Padres Lex.mos y q. como tal la criamos, y casamos; Dezpuez de q dho Narciso mi marido; la estrupo violentam.te sin atender q. era su P.e...de cuya Querella, no solo resulta la calumpnia Ynfamatoria contra la crianza, q nos deve, sino tambien el Despojo, q padesemos de ntros cortos vienes; Y siendo, siniestra la querella, ni concurrir la gravedad q. se supone de q. siendo Padre, huviese extrupado su hija; ni menos constarme á mi, q aun no siendo lo buviese executado; por tanto, recurro a Vm... f. $18-18 \mathrm{v}$.

9 ...si mediante á que la Dolores y su difunta muger no eran hermanas sino hijas ambas de Padres no conosidos, se podria casar con la Dolores para no dejarla desamparada... AGCA A2.2 Leg. 205 Exp. 4188 f. 8. 
10 Estimada Prenda de mi Corazon, y todo mi consuelo Maria Gaitan... Hija esta solo sirbe de partisiparte como lla poco falta q.e quiten de las piedras $y$ pongan en nosotros y por todas estas cosas y p.r bolber p.r tu credito $y$ el mio te mando esta para q.e sepaz q.e la intension q.e llebo en el Dia es q.e nos pongamos en estado. esto bajo tu pareser pues me abis de mandar abisar si es tu gusto para segir la istansia. esto tanto lo ago p.r la Bolunta q.e te tengo como p.r bolber p.r tu onor y tapar tanta boca pues el termino con q.e nos llaman es tan grosero q.e nos llaman p.r inses.tos y asi solo tu repuesta espero para escribirle al Sor. Cura y correr las delijensias que llo te prometo portarme como ombre de bien y quidarte como bos mereses. lo q.e si te digo es q.e bien es q.e no ai ningun inconbiniente. pues piensan q.e bos sos mi Cuñada y no q.e podemos cazarnos y asi no dejes de responderme lo mas pronto q.e podas...Domingo Morales. AGCA A2.2 Leg. 205 Exp. 4188 f. 14 -v.

11 ...ha alegado verbalm.te q.e sin embargo de que se estimaban y reputaban en el concepto publico por tales hermanas, en realidad no lo eran, sino solo de leche, p.r q.e su muger havia sido unicamente expuesta á las puertas de dha Manuela de Leon, y de su marido Pantaleon Gaitan...y q.e la dha M.a Dolores es hija lexitima de los nominados consortes... AGCA A2.2 Leg. 205 Exp. 4188 f. 16v.

12 ...p. a averiguarse con certeza de ser, ó no hermanas... AGCA A2.2 Leg. 205 Exp. 4188 f. 16v.

13 ...haviendo muerto los legitimos padres desta muchacha, y quedado enteram.te huerfana, el Padre Zapata tomando prenda en su seguridad, la huviese entregado a su hermana de leche, como asi lo ha dicho ultimamente el mismo Domingo procurando dismentir el concepto comun de que la Ramona su muger y la Maria Dolores fuesen hermanas en realidad. AGCA A2.2 Leg. 205 Exp. 4188 f. 25v.

14 ...p.r haver fallecido sus Padres, se havia venido la muchacha á buscarla y ella como Hermana mayor la havia recojido, y tenia en su poder... AGCA A2.2 Leg. 205 Exp. 4188 f. 28.

15 ...los expuextos, del mismo modo llaman, y reverencian p.r padres a los q.e los crian y mantienen... AGCA A2.2 Leg. 205 Exp. 4188 f. 29v.

16 ...dentro y fuera de casa se miran y tratan como hermanos. AGCA A2.2 Leg. 205 Exp. 4188 f. 29v.

17 Lo cierto es, q.e si Morales vivio en la duda de que propiam.te era cuñado de la Maria...desde luego no se le puede a Morales arguir de que cometiese incesto aun quando se le convenza de haver tenido trato ilicito con la Maria... AGCA A2.2 Leg. 205 Exp. 4188 f. 30-v.

18 ...efectivam.te no estaba en la creencia de que aquella era su Cuñada en realidad... AGCA A2.2 Leg. 205 Exp. 4188 f. 30v.

19 Si estaban en la intelig. a de q.e eran parientes tienen a su favor la presuncion mas fuerte y vehemente de honestidad. Si se tenian p.r libres de parentesco, no hai tal incesto, mayormente no haviendose probado el coito... AGCA A2.2 Leg. 205 Exp. 4188 f. 33v.

20 ...no cabe en la cabeza su perpetrasion, pues la misma naturaleza lo repugna... AGCA A1.15 Leg. 5390 Exp. 45725 f. 34v.

21 ...mirando el Amor q.e mi Marido, le tiene á sus Hijos como Padre al fin, me dijo, q.e á ella ce le ponia q.e mi Marido estava o tratava Ynlicitam.te con mi hija. respondiendole llo q.e no podia cer que ciempre era áci q.e p.a todos sus hijos era Amorozo. AGCA A1.15 Leg. 5426 Exp. 46305. 
22 ...tu heres la q.e mandas aqui, y no esa... AGCA A1.15 Leg. 5425 Exp. 46287 f. $3 \mathrm{v}$.

23 ...esta es Simona, esta sos vós... AGCA A1.15 Leg. 5425 Exp. 46287 f. 4.

24 ...si era chucha, que si no era su Padre, y le respondia que no le hacia, que si le sucedia alguna cosa, que el respondia por todo, que no tuviera miedo. A1.15 Leg. 2965 Exp. 28088 f. 4v-5.

25 ...las palabras que profirio para apagar el ardor de la pacion que le dominaba, y las contestaciones que la dió dirigidas á ablandar su constancia. AGCA A1.15 Leg. 5390 Exp. 45733 f. 6.

26 ...aunque ella se resistio diciendole que si no beia que lo miraban como a Padre, que como queria aser esas cosas estando casado con su Madre... AGCA A1 Leg. 2914 Exp. 27094 f. 10.

27 ...segura confianza del marido p.r aver este criado á la Juana aun desde pequeña y p.r esta razon tenerla p.r hija pues reciprocam.te assi le tratava en au[s]encia y pr[e]cencia de la madre. bastante fé era esta para no sospechar la mas Leve malicia. AGCA A1 Leg. 2914 Exp. 27094 19-v.

28 ...no era su madre que bien podian pecar...

29 José denied that he told Anica he would marry her, as he was aware of the impediment that stemmed from their relationship to one another. Anica initially denied, but then conceded, that she knew they were unable to marry.

30 ...pero luego que apagaron la candela se llegó [á] ella el dho Rivas á estarla forzando, y la declarante aunque se recistió con las reflexiones $d[e]$ que habia comulgado aquel dia, que tenia amistad con su hermana, y que finalmente no era su gusto, le contestó Rivas no tenia animo de casarse con su hermana, y aunque ultimamente le manifestó lo odioso que le era su perzona logró Rivas sus torpes deceos, pues no tubo á bien evitarlos gritando porque temió escandalizar á los que dormian halli, y que su honor lo padeciese... AGCA A2.2 Leg. 216 Exp. 4496 10v.

31 Pero lexos Sor. de obserbar en el un christiano proceder ha llegado á tal modo su infamia, q.e sin temer á Dios, á la Justicia ni a mi á desflorado violentam.te haze pocas horas á una Muchacha Sobrina mia q.e vive vajo de mi amparo... f. 1-v.

32 ...le decia á su marido, suelteme, no sea indigno p.r Maria Santissima, mire q.e se lo digo a su Muger pues yo soi donzella, y sobrina de su Muger: á que le contextaba, q.e aunq.e fuera, q.e media vez q.e el metia el pie en el lodo, lo sabia sacar, y q.e si se lo decia á la q.e declara, la havia de matar... f. 2.

33 ...aunq.e estaba avierta la puerta, y su Marido con su Sobrina en la cama. f. $2 \mathrm{v}$.

34 ...date prisa antes de que venga tu madre y tu muger... f. 2.

35 ...no queria de aquella suerte sino que subiese encima de ella... f. 2 .

36 ...ponerla en la Casa nueva p.r q. no era su Padre sino su Cuñado y q. le consta de positivo q. viven juntos como marido y muger y que su tienda es una Sodoma p.r la aguard.te y concurrencia q. alli hay en perjuicio a la R.l Universidad...

37 ...la Agustina publica q. Cantarillas es su Padre y como este és ya hombre grande y ella muy moza respecto del por este motivo podrán crerlo algunas personas...

38 ...en realidad no son pariente[s] sino que el le trata a la declarante tia por, cariño q.e le tiene.

39 See also AGCA A1.15 Leg. 2166 Exp. 15590. It includes an alleged (hyperbolic) comment about how one would find more than fifty women dressed as men in the convent of San Francisco de Guatemala at night. 
40 ...jamas ha tenido tal amistad, pues siempre ha tratado asi a la Ramona, como a sus otras Cuñadas, como hermanas....

41 ...el es temoroso de Dios, y sabe muy bien la gravedad del pecado q se le acomula, y nunca a tenido trato ilisito con ninguna de las dh.as sus dos nueras en obras ni en palabras por que siempre las á mirado, y atendido como a sus hijas propias...f. 7.

42 Though occasions for sponsorship in Latin America today can be quite numerous (see Foster 1953, 8), it is likely that the compadrazgo referred to below was associated with the rites of baptism or confirmation.

43 ...para q de esta suerte se esperimentase la ermienda con el parentesco contraido....

44 ...es su conp.e y mal pudiera comete tal....

45 ...primero se lo llevarian los diablos, antes que tal hiciese...f. $8 \mathrm{v}$.

46 ...para obiar esta ofensa le á ynstado ál susodho á que encompadren. f. $2 \mathrm{v}$.

47 María de la Concepción Palacios also hinted at the incompatibility of compadrazgo and sexual relations during interrogation about Benito Guerén's involvement with both her and her sister (Case 8). She admitted to an ilícita amistad with him in the past, "but year-to-date, she separated herself from it, making him a compadre through her son's confirmation."

48 See, for example, Foster (1953), Pitt-Rivers (1958), and Gudeman (1971).

49 ...si se halla (como dice dha su Madre estar violada) haver sido ótro el hechor; $y$ dha Muchacha, por salvar al que fue, (que pudo ser Perzona de su cariño) haver condenado á dho Francisco, con el dicere, de que fue su tio, para evadirse del castigo de su Madre. f. $7 \mathrm{v}$.

50 ...la ligereza, y temeridad con q.e la Josefa ha querido constituir á su Pad.e autor de su desfloramiento, y preñez. AGCA A2.2 Leg. 199 Exp. 4085 f. 7.

51 ...por encubrir su fragilidad, ha querido acriminar á su Pad.e...AGCA A2.2 Leg. 199 Exp. 4085 f. 8.

52 Lorenzo's surname was also written as Ratzzal, Ratztzal, and Ratzab.

53 ...le seria mas natural desirle a mi parte son vuestros mis hijos y no de Lorenzo, relevante prueva és sean de del predho. Ratzal, q.e confiesa su ilisito trato, q.e no de q.n se infiere...AGCA A1 Leg. 2914 Exp. 27094 f. 15v.

1 ...la rusticidad, é ignorancia de los Indios; principalm.te de las Mugeres... p.r esta razon no hay en los de esta clase el mismo dolo y malicia q.e en los de la otra para delinquir...conforme á lo prebenido p.r las Leyes, no debe imponerse la misma pena á los Indios, q.e a los Ladinos, sino q.e aquellos deben ser jusgados con equidad, y no con el rigor, q.e disponen las mismas Leyes se jusgue á estos...

2 Era pues presiso un impulso, y movimiento, extraordinario de la bondad, y poder de Dios, p.a sostener á Hernandes en una provocasion tan singular como esta; y mas viviendo junto[s] en donde no podia resistir a los ruegos, y lagrimas, de una Madrastra zelosa, y afligida, q.e hasta la salid[a] á Misa le negaba, p.r pareserle, q.e iba a buscar otr[a] Muger. ¿Que podia pues esperarse de un Pobre Yndi[o]; en quien la ignorancia, y rustisidad caminan juntas? El mayor santo huviera caido; co[n] semejante provocasion...

3 ...parece que debe mirarse con alguna eguidad quando se comete por Yndios, cuia ignorancia funda á su favor la presuncion de no proceder con la malicia que se supone en los de las otras castas. $\mathrm{f} .7 \mathrm{v}$.

4 Reference to this law also surfaced in Case 54.

5 ...deb [e] suponerse mas adelantada su sivilizacion (á lo menos respecto de la Religion Cristiana) q.e en los immediatos á la Conquista... f. $7 \mathrm{v}$.

6 It is noteworthy that Mariano identified himself as mestizo, yet he was elsewhere described as indio tributario and evidently treated as if he were Indian. 
7 ...la torpeza de los Yndios, é indiferencia con que regularm.te ven el delito de incesto, les hace caer en el, q.do la ocasion se les presenta. f. 10.

8 ... de la rusticidad de los Yndios y del poco escrupulo con que cometen delitos de esta clase... f. 10v.

9 Se ha dicho ser Ynd.s los delinquentes, con lo q. se dijo todo sobre esta particular, combiniendo el modo con q.e se portan en q.to al sexto, con lo q.e cantó Ovidio de otras gentes muy parecidas á nros. naturales entre las q.e indiferentem.te se mesclaban el Padre con la hija, y el hijo con la madre... f. 13.

10 ...aunque es mi padre pero no por eso a de salirse con el echo pues no sera cristiandad ni profesaremos la fe de Jesucristo por lo que pido contra Bisente Fuentes por aber anulado mi matrimonio y el suyo abiendo yegado a tener auto fordadamente con mi muger por dos veses por lo que en meritos de Justicia pido un destierro para toda su bida...prosediendo yo a no juntarme con eya por ninguna manera por que no sera rrazon que yo mismo Busque esa sal pais. Bien sabe el Senor General el delito que se tiene pues es mi padre, y faltara yo a ser cristiano si n[o] lo hiziera asi y en meritos de Justici[a] pido que lo destierren para toda su bida a un castiyo...que yo estando el no me junto con eya aunque egecuten en si el quastigo que el Senor General mandara... AGCA A1.15 Leg. 2965 Exp. 28088 f. 1-v.

11 When José said he would "not reunite with her by any means," he used the verb juntarse, which also referred to sexual intercourse (see Diccionario de Autoridades $1726-1739$ v. 4).

12 Thomas Gage ([1648] 1958, 204) used the term "salt earth" when discussing salt production in Amatitlán, noting how mules were brought there to feed on the "salt earth."

13 ...pensando se huviese mesclado con otro hombre estraño carnalmente, y resultó que su mismo Padre del que expone Vicente Fuentes, fue el que cometió este crimen, por lo qual se presento a la Justicia para que se le escarmiente. AGCA A1.15 Leg. 2965 Exp. 28088 f. 3v.

14 Following an appeal, Vicente and Rosalía were assigned new legal representatives.

15 ...procuró persuadir a su Suegro a fin de que contubiese su impetu, haciendole ver que era su hija politica, y que semejantes procedimientos quedaban para los irracionales, y no se obcerbaban entre Cristianos...pero a pesar de esto Fuentes no hiso caso de estos combencimientos tan naturales, y por el contrario la insistia a que no tubiese miedo... AGCA A1.15 Leg. 2965 Exp. 28088 f. 8.

16 ...no supo lo que se hiso, ni la gravedad del pecado que cometia, y pide se le mire con conmiseracion. AGCA A1.15 Leg. 2965 Exp. 28088 f. 6v.

17 Pero que queremos que practiquen unas jentes yncultas, unas jentes ynbrutesidas, unas jentes sin temor, ni respeto á D.s pues Esta En desir, que los Yndios p.r mas cognato q.e pongan sus Curas en ynstruirlos, Estan hasta El dia por conquistar... AGCA A1.15 Leg. 2965 Exp. 28088 f. 9v.

18 ...falto de los principios racionales se deliberó á pecar... AGCA A1.15 Leg. 5390 Exp. 45733 f. $3 \mathrm{v}$.

19 Aunque Yndio rustico Vicente, y sin las luces necesarias de religion, despues de cometido su delito, lo conoció, é infirió su gravedad, y p.r esto impuso á su nuera perpetuo silencio, creyendo q.e con esto todo se havia concluido, y hechadosele trra y q.e con no bolverla á solicitar mas, cumpliria con Dios, y con la lealtad q.e debia guardar á su hijo: tales son los sentimientos sencillos, y nada maliciosos de los Yndios en esta parte, pues como en ellos no resplandecen las luces de religion y caridad, q.e en los cultos, se hacen acrehedores á la conmiseracion. AGCA A1.15 Leg. 5390 Exp. 45733 f. 18. Charity is a theological virtue that refers to loving God above all things for his sake and loving others for God's sake. Religion, a moral virtue with which God is revered, is born from the theological virtue of Charity. See, for example, Diccionario de Autoridades (1726-1739 v. 2, v. 5). 
20 Quantos exemplos se leen en las Historias, de Mugeres que habiendo cuidado extrabordinariamente de la pureza, han caido por ultimo en las artificiosas trampas de un disoluto; y quien no advierte, que aunque sus cuerpos quedaron manchados, sus virtudes se han hecho mas admirables. AGCA A1.15 Leg. 5390 Exp. 45733 f. 5v-6.

21 ...la union corporal de Padres é hijas era la mas monstruosa, vista solamente entre los animales. AGCA A1.15 Leg. 5390 Exp. 45733 f. 7.

22 ...los inesperados movimientos de su suegro...la extraña inclinacion de que estaba poseido...la necia pretencion de su Padre. AGCA A1.15 Leg. 5390 Exp. 45733 f. 7-v.

23 Los réspetós de su Padre, y él temór de no levantar la la mano contra el, la impedirian hacer los esfuerzos posibles en su defénsa; asi como quando un hijo es reprendido de su Padre injustamente, no se atreve á contradecir, ni usar de sus derechos, por el miedo de incurrir en alguna falta. No debe dudarse tampoco que la Rosalia Surquiah esta imbuida en el érror comun de las gentes idiotas, que á los Padres debe obedecerse hasta en los mandatos pecaminosos; por que su condicion, y principios de govierno no pronostican otra cosa. AGCA A1.15 Leg. 5390 Exp. 45733 f. 7v.

24 ...la sensualidad es la pacion que mas dificilmente se vence; por cuyo motivo aseverare, sin temor de errar, que es el escalon mas trabajoso para los justos, que continuamente exercitan su cuerpo con asperas penitencias, $y$ q.e ha sido la causa del trastorno de ilustratos entendimientos... Y haciendo tantos extragos, y en tales Personas. ¿Que se debe esperar de una Yndia rustica sin principios de Religion, que no tiene otra regla para obrar que su propia voluntad? AGCA A1.15 Leg. 5390 Exp. 45733 f. 8.

25 ...es bien savido que entre los Yndios ay unos que tienen mas malicia que otros... AGCA A1.15 Leg. 5390 Exp. 45733 f. 14.

26 Compare with Lewis's (1995) analysis of a witchcraft case involving two free black women. Lewis found that, to her benefit, the defendant and her defenders were able to portray her as "not black" and "not female," two characteristics typically associated with witchcraft and viewed as inferior following racial and gender hierarchies that privileged Spanish and male statuses.

27 See, for example, Bertrand 1989, 163.

28 Her surname was also written as Sotoh and Tzoh.

29 ...la falta de instruccion y menos malicia q.e ordinariam.te o por lo comun se advierte en los de nuestra clase... AGCA A1.15 Leg. 5390 Exp. 45733 f. 20v.

30 ...aunque le dijo q.e savia que estava con su ermana en ilicita amistad con palabra de casamiento, le respondio Quachita, q.e no le asia, q.e si resultava preñada se llevaria la criatura a criar a su casa, y con este motivo se metio con él, de q.e a resultado embarasada... f. 3.

31 ...p.r su ig[no]rancia nunca penetró el delito q.e cometio n[i] que fuese motibo de q.e se impidiese el casamiento q.e Quachito tenia propuesto a su hermana... f. $5 \mathrm{v}-6$.

32 Though Bernardo had said that he was not sure whether they were whole sisters or not.

33 ...enorme delito...en haver mantenido concubinato incestuoso con las dos Marias...sabiendo de positivo q.e son ermanas...semejantes exésos solo entre los irracionales se ven...como hombre fragil, $y$ sin estos sentimientos cristianos, no graduó la enormidad q.e cometia en estos exésos de q.e se le hace cargo... f. 5 .

34 ...por su calidad é ignorancia se disminuye mucho su criminalidad, y gravedad...f. $17 \mathrm{v}$.

35 ...temerosa de que su Padre hiciese lo mismo con la que declara lo haviso al Alcalde del lugar, no habiendolo hecho antes por falta de advertencia, 
y se halla en el dia entregada en otra casa en donde le estan enseñando la doctrina pues su Padre no lo hacia...

36 ...si acaso es bruto para haber hecho semejante pecado, que sus Padres le criaron, y educaron con temor á Dios... f. 2.

37 ...ninguno Que es hermana de Madre, de Petrona Martel, q.e fue su muger lexitima pero q.e heran hijas de distintos Padres. f. $5 \mathrm{v}$.

38 ...como tonto q.e es, no save. f. $5 \mathrm{v}$.

39 ...lo hizo con el fin de casarse y como tonto no savia lo q.e hacia. f. 5v.

40 ...lo que no deve hacer fuerza, si se considera el Idiotismo que es tan proprio en los de su clase, y calidad. f. 8.

41 ...todo és verdad; pero q.e como era tonta, no sabia lo mal q.e hacia, hasta ahora q.e se lo han dicho. f. 8.

42 ...no puede ignorarlo, p.r ser cosa muy sabida aun entre las gentes mas burdas q.e el trato torpe de un mismo hombre con dos hermanas carnales es un nuebo delito, á mas de el de la simple fornicacion, y q.e en el p.r sus circunstancias de saber leer y escribir, y la de haverse rosado con gentes no se puede suponer la ignorancia q.e aparenta...

43 This does not include incidents where individuals were unaware due to intoxication, did not realize their relatives had a sexual relationship with the same person as them, or misunderstood the nature of a relationship like when Domingo Morales from Chapter 4 did not believe his deceased wife was the sister of the woman he wanted to marry.

44 Juan José's surname was also spelled Pisabah, Pixavag, and Pixabah.

45 ...hombre q.e es esto somos cristianos asi se cumple la Ley de Dios como es esto con tu hija... AGCA A1.15 Leg. 3028 Exp. 29261 f. $2 \mathrm{v}$.

46 ...entre los Yndios y los que se crian a estilo de ellos, el delito de incesto, lo mismo q.e la embriaguez (como dice el P.e Avendaño, y apunta el S.or Solo[r]zano) no es de los pecados de mayor gravedad, por no tener la comprehension de su malicia... AGCA A1.15 Leg. 3028 Exp. 29261 f. 11.

47 ...el incesto cometido p.r Manuel Salvatierra con su hija lexitima Manuela es uno de aquellos delitos mas avominables q. puedan contarse entre los lacibos pues aun la misma naturaleza se orroriza de ellos.

48 ...el pecado de insesto es casi tan comun entre los Yndios como el de la embriaguez; pero el q. se comete en el primer grado de Padre con hija aun entre los Yndios gentiles se vio con repugnansia...

49 ...un hombre á quien naturalm.te debe respetar y temer.

50 ...estava ebrio en terminos de no saver lo que hacia. AGCA A1.15 Leg. 2965 Exp. 28088 f. 3.

51 ...no ha cometido tal delito, a menos que lo haya executado bolo, y no se acuerde. AGCA A1.15 Leg. 2965 Exp. 28088 f. 4v.

52 ...nunca estaba ebrio, aunque algunas besses havia tomado águardiente, y q.e nunca há padecido de locura ni de ótra falta de sentidos... f. 10v.

53 ...pensando que era su muger tubo acto carnal con su hija de lo que se arrepintio al dia siguiente. AGCA A2.2 Leg. 199 Exp. 4085 f. 4v.

54 Es constante, que Garcia tuvo un simple acceso con su hija; pero igualm.te lo es, q.e fué estando fuera de si, ó en terminos, q.e no sabia lo que hacia; p.r q.e se hallaba poseido de la ebriedad...cuya circunstancia es bastante en el concepto legal p.a escusarle de la pena ordinaria... AGCA A2.2 Leg. 199 Exp. 4085 f. 8.

55 ...quando el suceso no estava bolo p.r entero sino es medio tomado, y p.r eso se acuerda que la muchacha le dio palabra en aquel acto... f. $9 \mathrm{v}$.

56 ...nunca pudiera haver condesendido siendo hasi que no savia por razon de su estado p.a que pudiera combidarla... f. 9.

57 ...la tosca educasion, no los saca y antes los establese mas, en una estulticia de prim.a orden, q.e los dispenza de la pena ordinaria de las Leyes... 
cuia execpcion se prepondera en los exesos de torpeza donde la frajilid[ad] obra á proporcion de la poca resistencia q.e encuentra, respecto á la ninguna educasion, y falta de reconocim.to de la Religion y sus sagradas Leyes. f. 11-v.

1 ...comenzó a llamarlo carinosamente, diziendole veni tata quitate de ay. f. 2 .

2 In Guatemala, civil marriage and divorce was formalized in 1836 and 1837 only to be returned to ecclesiastical jurisdiction a few months later following a rebellion that ousted the liberal government. It was not until 1877 that the state was again granted shared jurisdiction over marriage and divorce (Komisaruk 2013, 248-9).

3 This included the wife of an adoptive father and, presumably, the husband of an adoptive mother.

\section{Bibliography}

Bamford, Sandra, and James Leach. 2009. "Introduction: Pedigrees of Knowledge: Anthropology and the Genealogical Method." In Kinship and Beyond: The Genealogical Model Reconsidered, edited by Sandra Bamford and James Leach, 1-23. New York and Oxford: Berghahn Books.

Boyer, Richard. 1989. "Women, La Mala Vida, and the Politics of Marriage." In Sexuality and Marriage in Colonial Latin America, edited by Asunción Lavrin, 252-86. Lincoln and London: University of Nebraska Press.

Burns, Kathryn. 2010. Into the Archive: Writing and Power in Colonial Peru. Durham, NC and London: Duke University Press.

Carsten, Janet. 2000a. "Introduction: Cultures of Relatedness." In Cultures of Relatedness: New Approaches to the Study of Kinship, edited by Janet Carsten, 1-36. Cambridge: Cambridge University Press. . ed. 2000b. Cultures of Relatedness: New Approaches to the Study of Kinship. Cambridge: Cambridge University Press.

- 2001. "Substantivism, Antisubstantivism, and Anti-antisubstantivism." In Relative Values: Reconfiguring Kinship Studies, edited by Sarah Franklin and Susan McKinnon, 29-53. Durham, NC and London: Duke University Press.

- 2004. After Kinship. Cambridge: Cambridge University Press.

Castañeda, Carmen. 1989. Violación, estupro, y sexualidad: Nueva Galicia, 1790-1821. Guadalajara: Hexágano.

Collier, Jane Fishburne, and Sylvia Junko Yanagisako. 1987. "Introduction.” In Gender and Kinship: Essays toward a Unified Analysis, edited by Jane Fishburne Collier and Sylvia Junko Yanagisako, 1-50. Stanford, CA: Stanford University Press.

Cutter, Charles R. 1995. The Legal Culture of Northern New Spain, 17001810. Albuquerque: University of New Mexico Press.

Fox, Robin. 1980. The Red Lamp of Incest. New York: E. P. Dutton.

Franklin, Sarah. 2013. Biological Relatives: IVF, Stem Cells, and the Future of Kinship. Durham, NC and London: Duke University Press. 
Franklin, Sarah, and Susan McKinnon, eds. 2001. Relative Values: Reconfiguring Kinship Studies. Durham, NC and London: Duke University Press.

Goody, Jack. 1956. "A Comparative Approach to Incest and Adultery." The British Journal of Sociology 7 (4): 286-305.

Héritier, Françoise. 2002. Two Sisters and Their Mother: The Anthropology of Incest. Translated by Jeanine Herman. New York: Zone Books.

Herman, Judith Lewis. 2000. Father-Daughter Incest. Cambridge and London: Harvard University Press.

Howell, Signe. 2001. "Self-Conscious Kinship: Some Contested Values in Norwegian Transnational Adoption." In Relative Values: Reconfiguring Kinship Studies, edited by Sarah Franklin and Susan McKinnon, 203-23. Durham, NC and London: Duke University Press.

Jaffary, Nora E. 2007. "Incest, Sexual Virtue, and Mobility in Late Colonial Mexico." In Gender, Race, and Religion in the Colonization of the Americas, edited by Nora E. Jaffary, 95-107. Hampshire: Ashgate.

Kellogg, Susan. 1995. Law and the Transformation of Aztec Culture, 15001700. Norman: University of Oklahoma Press.

Komisaruk, Catherine. 2008. "Rape Narratives, Rape Silences: Sexual Violence and Judicial Testimony in Colonial Guatemala.” Biography 31 (3): 369-96.

-2013. Labor and Love in Guatemala: The Eve of Independence. Stanford, CA: Stanford University Press.

Kulick, Don. 1996. "Causing a Commotion.” Anthropology Today 12 (6): 3-7.

Lévi-Strauss, Claude. 1969. The Elementary Structures of Kinship. Boston, MA: Beacon Press.

Lipsett-Rivera, Sonya. 1997. "The Intersection of Rape and Marriage in Late-Colonial and Early-National Mexico.” CLAHR 6 (4): 559-90.

Lutz, Christopher H. 1994. Santiago de Guatemala, 1541-1773: City, Caste, and the Colonial Experience. Norman and London: University of Oklahoma Press.

Margadant, Guillermo Floris. 2001. "El concepto de incesto aplicado por la justicia eclesiástica en la Nueva España y en el México independiente preliberal." In La sexofobia del clero y cuatro ensayos histórico-jurídicos sobre sexualidad, edited by Guillermo Floris Margadant, 61-95. México: Miguel Ángel Porrúa.

Merry, Sally Engle. 1991. "Law and Colonialism." Law and Society Review 25 (4): 889-922.

- 1994. "Courts as Performances: Domestic Violence Hearings in a Hawai'i Family Court." In Contested States: Law, Hegemony and Resistance, edited by Mindie Lazarus-Black and Susan F. Hirsch, 35-58. New York and London: Routledge.

Ortner, Sherry B. 1972. "Is Female to Male as Nature Is to Culture?" Feminist Studies 1 (2): 5-31.

Parkin, Robert, and Linda Stone. 2004. "General Introduction.” In Kinship and Family: An Anthropological Reader, edited by Robert Parkin and Linda Stone, 1-23. Malden, MA, Oxford, and Carlton: Blackwell Publishing.

Penyak, Lee M. 2016. "Incestuous Natures: Consensual and Forced Relations in Mexico, 1740-1854." In Sexuality and the Unnatural in Colonial Latin America, edited by Zeb Tortorici, 162-87. Oakland: University of California Press.

Premo, Bianca. 2005. Children of the Father King: Youth, Authority, and Legal Minority in Colonial Lima. Chapel Hill: University of North Carolina Press. 
Rodríguez-Sáenz, Eugenia. 2005. “'Tiyita bea lo que me han hecho’: estupro y incesto en Costa Rica (1800-1850).” In El paso del cometa: estado, política social y culturas populares en Costa Rica (1800-1950), edited by Iván Molina Jiménez and Steven Palmer, 1-47. San José, Costa Rica: EUNED.

Rosaldo, Michelle Zimbalist. 1974. "Woman, Culture, and Society: A Theoretical Overview." In Woman, Culture and Society, edited by Michelle Zimbalist Rosaldo and Louise Lamphere, 17-42. Stanford, CA: Stanford University Press.

Rubin, Gayle. 1975. “The Traffic in Women: Notes on the 'Political Economy' of Sex." In Toward an Anthropology of Women, edited by Rayna R. Reiter, 157-210. New York and London: Monthly Review Press.

Saffa, Sarah N. 2019. "'She Was What They Call a "Pepe"': Kinship Practice and Incest Codes in Late Colonial Guatemala." Journal of Family History 44 (2): 181-99.

Schneider, David M. 1984. A Critique of the Study of Kinship. Ann Arbor: University of Michigan Press.

Stern, Steve J. 1995. The Secret History of Gender: Women, Men, and Power in Late Colonial Mexico. Chapel Hill and London: University of North Carolina Press.

Stone, Linda. 2004. "Introduction.” In Kinship and Family: An Anthropological Reader, edited by Robert Parkin and Linda Stone, 331-41. Malden, MA, Oxford, and Carlton: Blackwell Publishing.

Strathern, Marilyn. 2005. Kinship, Law and the Unexpected: Relatives Are Always a Surprise. Cambridge and New York: Cambridge University Press.

Tortorici, Zeb. 2015. "Sexual Violence, Predatory Masculinity, and Medical Testimony in New Spain." Osiris 30: 272-94.

-2018. Sins against Nature: Sex and Archives in Colonial New Spain. Durham, NC and London: Duke University Press.

Twinam, Ann. 1999. Public Lives, Private Secrets: Gender, Honor, Sexuality, and Illegitimacy in Colonial Spanish America. Stanford, CA: Stanford University Press.

Weston, Kath. 1991. Families We Choose: Lesbians, Gays, Kinship. New York: Columbia University Press.

. 1995. "Forever Is a Long Time: Romancing the Real in Gay Kinship Ideologies." In Naturalizing Power: Essays in Feminist Cultural Analysis, edited by Sylvia Yanagisako and Carol Delaney, 87-110. New York and London: Routledge.

- 2001. "Kinship, Controversy, and the Sharing of Substance: The Race/ Class Politics of Blood Transfusion." In Relative Values: Reconfiguring Kinship Studies, edited by Sarah Franklin and Susan McKinnon, 147-74. Durham, NC and London: Duke University Press.

Yan, Yunxiang. 2001. "Practicing Kinship in Rural North China.” In Relative Values: Reconfiguring Kinship Studies, edited by Sarah Franklin and Susan McKinnon, 224-45. Durham, NC and London: Duke University Press.

Borah, Woodrow. 1983. Justice by Insurance: The General Indian Court of Colonial Mexico and the Legal Aides of the Half-Real. Berkeley, Los Angeles, London: University of California Press.

Burkhart, Louise M. 2001. "Gender in Nahuatl Texts of the Early Colonial Period: Native 'Tradition' and the Dialogue with Christianity." In Gender in Pre-Hispanic America, edited by Cecelia F. Klein, 87-107. Washington, DC: Dumbarton Oaks.

Castañeda, Carmen. 1989. Violación, estupro, y sexualidad: Nueva Galicia, 1790-1821. Guadalajara: Hexágano. 
Clendinnen, Inga. 1982. "Yucatec Maya Women and the Spanish Conquest: Role and Ritual in Historical Reconstruction." Journal of Social History 15 (3): 427-42.

Gacto Fernández, Enrique. 1969. La filiación no legítima en el derecho histórico español. Seville: Universidad de Sevilla.

González S., Leticia, and Ann Jefferson. 1995. "Sexualidad femenina en el oriente de Guatemala, vista a través de las dispensas matrimoniales, siglo XIX.” In Memoria del Segundo Encuentro Nacional de Historiadores del 4 al 6 del diciembre de 1995, 91-110. Guatemala: Universidad del Valle de Guatemala.

Hale, Charles R. 2006. Más Que Un Indio: Racial Ambivalence and Neoliberal Multiculturalism in Guatemala. Santa Fe: School of American Research Press.

Haskett, Robert. 1991. Indigenous Rulers: An Ethnohistory of Town Government in Colonial Cuernavaca. Albuquerque: University of New Mexico Press.

Herman, Judith Lewis. 2000. Father-Daughter Incest. Cambridge and London: Harvard University Press.

Herrera, Robinson A. 2003. Natives, Europeans, and Africans in SixteenthCentury Santiago de Guatemala. Austin: University of Texas Press.

—. 2007. "Concubines and Wives: Re-Interpreting Native-Spanish Intimate Unions in Sixteenth-Century Guatemala." In Indian Conquistadors: Indigenous Allies in the Conquest of Mesoamerica, edited by Michel Oudijk and Laura Matthew, 127-44. Norman: University of Oklahoma Press.

Hill, II, Robert M. 2002. Colonial Cakchiquels: Highland Maya Adaptation to Spanish Rule, 1600-1700. Belmont, CA: Thomson Wadsworth.

—. 2012. "Three Families: Geneologies and Processes among the SixteenthCentury Kaqchikel Maya.” Ethnohistory 59 (3): 469-596.

Hill, II, Robert M., and John Monaghan. 1987. Continuities in Highland Maya Social Organization: Ethnohistory in Sacapulas, Guatemala. Philadelphia: University of Pennsylvania Press.

Jaffary, Nora E. 2007. "Incest, Sexual Virtue, and Mobility in Late Colonial Mexico." In Gender, Race, and Religion in the Colonization of the Americas, edited by Nora E. Jaffary, 95-107. Hampshire: Ashgate.

Johnson, Lyman L., and Sonya Lipsett-Rivera. 1998a. "Introduction." In The Faces of Honor: Sex, Shame, and Violence in Colonial Latin America, edited by Lyman L. Johnson and Sonya Lipsett-Rivera, 1-17. Albuquerque: University of New Mexico Press.

- eds. 1998b. The Faces of Honor: Sex, Shame, and Violence in Colonial Latin America. Albuquerque: University of New Mexico Press.

Kellogg, Susan. 1995. Law and the Transformation of Aztec Culture, 15001700. Norman: University of Oklahoma Press.

Komisaruk, Catherine. 2013. Labor and Love in Guatemala: The Eve of Independence. Stanford, CA: Stanford University Press.

Kuznesof, Elizabeth A. 1995. "Ethnic and Gender Influences on 'Spanish' Creole Society in Colonial Spanish America." Colonial Latin American Historical Review 4 (1): 153-76.

Lokken, Paul. 2001. "Marriage as Slave Emancipation in 17th Century Guatemala." The Americas 58 (2): 175-200.

Luján Muñoz, Jorge. 1976. "Fundaciones de villas de ladinos en Guatemala en el último tercio del siglo XVIII.” Revista de Indias 36 (145-146): 51-81. 
1983. "Changes in the Family Structure of the Pokomam of Petapa, Guatemala in the First Half of the 16th Century." Journal of Comparative Family Studies 14 (2): 215-27.

Lutz, Christopher H. 1994. Santiago de Guatemala, 1541-1773: City, Caste, and the Colonial Experience. Norman and London: University of Oklahoma Press.

Lutz, Christopher H., and W. George Lovell. 1990. "Core and Periphery in Colonial Guatemala." In Guatemalan Indians and the State, 1540-1988, edited by Carol A. Smith, 35-51. Austin: University of Texas Press.

MacLeod, Murdo J. 1973. Spanish Central America: A Socioeconomic History, 1520-1720. Berkeley: University of California Press.

McCaa, Robert. 2003. "The Nahua calli of Ancient Mexico: Household, Family, and Gender." Continuity and Change 18 (1): 23-48.

Milton, Cynthia E., and Vinson, III, Ben. 2002. "Counting Heads: Race and Non-Native Tribute Policy in Colonial Spanish America." Journal of Colonialism and Colonial History 3 (3): 1-18.

Offutt, Leslie S. 1997. "Women's Voices from the Frontier: San Esteban de Nueva Tlaxcala in the Late Eighteenth Century." In Indian Women of Early Mexico, edited by Susan Schroeder, Stephanie Wood, and Robert Haskett, 273-89. Norman and London: University of Oklahoma.

Penyak, Lee M. 2016. "Incestuous Natures: Consensual and Forced Relations in Mexico, 1740-1854." In Sexuality and the Unnatural in Colonial Latin America, edited by Zeb Tortorici, 162-87. Oakland: University of California Press.

Premo, Bianca. 2005. Children of the Father King: Youth, Authority, and Legal Minority in Colonial Lima. Chapel Hill: University of North Carolina Press.

Restall, Matthew. 1997. The Maya World: Yucatec Culture and Society, 15501850. Stanford, CA: Stanford University Press.

Rípodas Ardanaz, Daisy. 1977. El matrimonio en Indias: realidad social y regulación jurídica. Buenos Aires, Argentina: Fundación para la Educación, la Ciencia, y la Cultura.

Rodríguez Jiménez, Pablo. 1988. "Matrimonio incestuoso en el Medellín colonial 1700-1810.” Revista Extensión Cultural 24-25: 52-8.

Rodríguez-Sáenz, Eugenia. 2005. “'Tiyita bea lo que me han hecho’: estupro y incesto en Costa Rica (1800-1850)." In El paso del cometa: estado, política social y culturas populares en Costa Rica (1800-1950), edited by Iván Molina Jiménez and Steven Palmer, 1-47. San José, Costa Rica: EUNED.

Rojas Flores, Jorge. 2007. "Ursula: The Life and Times of an Aristocratic Girl in Santiago, Chile (1666-1678)." In Raising an Empire: Children in Early Modern Iberia and Colonial Latin America, edited by Ondina E González and Bianca Premo, 107-36. Albuquerque: University of New Mexico Press.

Sanchiz Ochoa, Pilar. 1980. "Cambio en la estructura familiar indígena: Influencias de la Iglesia y la Encomienda en Guatemala." Revista de la Universidad Complutense 28: 169-91.

Schroeder, Susan, Stephanie Wood, and Robert Haskett, eds. 1997. Indian Women of Early Mexico. Norman and London: University of Oklahoma Press.

Schwaller, John Frederick. 2011. The History of the Catholic Church in Latin America: From Conquest to Revolution and Beyond. New York and London: New York University Press. 
Schwaller, Robert C. 2016. Géneros de Gente in Early Colonial Mexico: Defining Racial Difference. Norman: University of Oklahoma Press.

Schwartzkopf, Stacey. 2013. "Rural Castas, State Projects, and Ethnic Transformation in Western Guatemala, 1800-1821." Ethnohistory 60 (4): 721-47.

Sherman, William L. 1979. Forced Native Labor in Sixteenth-Century Central America. Lincoln and London: University of Nebraska Press.

Socolow, Susan Migden. 1980. "Women and Crime: Buenos Aires, 1757-97." Journal of Latin American Studies 12 (1): 39-54.

2015. The Women of Colonial Latin America. 2nd ed. New York: Cambridge University Press.

Solano, Francisco de. 1969. "Areas lingüísticas y población de habla indígena de Guatemala en 1772." Revista Española de Antropología Americana 4: 145-200.

Stern, Steve J. 1995. The Secret History of Gender: Women, Men, and Power in Late Colonial Mexico. Chapel Hill and London: University of North Carolina Press.

Taracena Arriola, Arturo. 1982. "Contribución al estudio del vocablo 'ladino' en Guatemala (S. XVI-XIX).” In Historia y antropología de guatemala: ensayos en honor de J. Daniel Contreras R., edited by Jorge Luján Muñoz, 89-104. Guatemala: Universidad de San Carlos de Guatemala.

Taylor, William B. 1979. Drinking, Homicide, and Rebellion in Colonial Mexican Villages. Stanford, CA: Stanford University Press.

Terraciano, Kevin. 1998. "Crime and Culture in Colonial Mexico: The Case of the Mixtec Murder Note.” Ethnohistory 45 (4): 709-45.

Twinam, Ann. 1999. Public Lives, Private Secrets: Gender, Honor, Sexuality, and Illegitimacy in Colonial Spanish America. Stanford, CA: Stanford University Press.

- 2007. "The Church, the State, and the Abandoned: Expósitos in Late Eighteenth-Century Havana." In Raising an Empire: Children in Early Modern Iberia and Colonial Latin America, edited by Ondina E. González and Bianca Premo, 163-86. Albuquerque: University of New Mexico Press.

van Deusen, Nancy E. 2015. Global Indios: The Indigenous Struggle for Justice in Sixteenth-Century Spain. Durham, NC and London: Duke University Press.

van Oss, Adriaan C. 1986. Catholic Colonialism: A Parish History of Guatemala, 1524-1821. Cambridge: Cambridge University Press.

Waldron, Kathy. 1989. "The Sinners and the Bishop in Colonial Venezuela: The Visita of Bishop Mariano Martí, 1771-1784." In Sexuality and Marriage in Colonial Latin America, edited by Asunción Lavrin, 156-77. Lincoln and London: University of Nebraska Press.

Aguirre, Carlos, and Ricardo D. Salvatore. 2001. "Writing the History of Law, Crime, and Punishment in Latin America." In Crime and Punishment in Latin America: Law and Society Since Late Colonial Times, edited by Ricardo D. Salvatore, Carlos Aguirre, and Gilbert M. Joseph, 1-32. Durham, NC and London: Duke University Press.

Archibald, Elizabeth. 2001. Incest and the Medieval Imagination. Oxford: Clarendon Press.

Borah, Woodrow. 1982. "The Spanish and Indian Law: New Spain." In The Inca and Aztec States, 1400-1800: Anthropology and History, edited by George A. Collier, Renato I. Rosaldo, and John D. Wirth, 265-88. New York and London: Academic Press. 
1983. Justice by Insurance: The General Indian Court of Colonial Mexico and the Legal Aides of the Half-Real. Berkeley, Los Angeles, London: University of California Press.

Buckley, Theodore Alois. 2014. The Canons and Decrees of the Council of Trent. London: Aeterna Press. Kindle.

Burkhart, Louise M., and Janine Gasco. 2007. "The Colonial Period in Mesoamerica." In The Legacy of Mesoamerica: History and Culture of a Native American Civilization, edited by Robert M. Carmack, Janine Gasco, and Gary H. Gossen, 2nd ed., 182-221. Upper Saddle River, NJ: Pearson Prentice Hall.

Burkholder, Mark A., and D. S. Chandler. 1977. From Impotence to Authority: The Spanish Crown and the American Audiencias, 1687-1808. Columbia: University of Missouri Press.

Castañeda, Carmen. 1983. "La memoria y las niñas violadas." In La memoria y el olvido: Segundo Simposio de Historia de las Mentalidades, 107-15. Mexico City: UNAM.

—. 1989. Violación, estupro, y sexualidad: Nueva Galicia, 1790-1821. Guadalajara: Hexágano.

Covarrubias Orozco, Sebastián de. 1611. Tesoro de la lengua castellana, o española. Madrid: Luis Sánchez. Google Books.

Cunningham, Charles Henry. 1919. The Audiencia in the Spanish Colonies: As Illustrated by the Audiencia of Manila (1583-1800). Berkeley: University of California Press.

Cutter, Charles R. 1995. The Legal Culture of Northern New Spain, 17001810. Albuquerque: University of New Mexico Press.

Diccionario de Autoridades. 1726-1739. 6 vols. Madrid: Real Academia Española. http://web.frl.es/DA.html.

Dillard, Heath. 1976. "Women in Reconquest Castile: The Fueros of Sepúlveda and Cuenca." In Women in Medieval Society, edited by S. M. Stuard, 71-94. Philadelphia: University of Pennsylvania Press.

Escriche, Joaquín. 1874-1876. Diccionario razonado de legislación y jurisprudencia. 4 vols. Madrid: Eduardo Cuesta. https://catalog.hathitrust.org/ Record/009264676

Few, Martha. 2000. "On Her Deathbed, María de la Candelaria Accuses Michaela de Molina of Casting Spells." In Colonial Lives: Documents on Latin American History, 1550-1850, edited by Richard Boyer and Geoffrey Spurling, 166-77. New York and Oxford: Oxford University Press.

Fox, Robin. 1980. The Red Lamp of Incest. New York: E. P. Dutton.

Fuentes y Guzmán, Francisco Antonio de. (1690) 1882. Historia de Guatemala: ó Recordación Florida, edited by Justo Zaragoza. Madrid: Luis Navarro.

Goody, Jack. 1956. "A Comparative Approach to Incest and Adultery." The British Journal of Sociology 7 (4): 286-305.

- 1983. The Development of the Family and Marriage in Europe. Cambridge: Cambridge University Press.

Hill, II, Robert M. 1989. "Social Organization by Decree in Colonial Highland Guatemala.” Ethnohistory 36 (2): 170-98.

- 2002. Colonial Cakchiquels: Highland Maya Adaptation to Spanish Rule, 1600-1700. Belmont, CA: Thomson Wadsworth.

Jones, Jr., Oakah L. 1994. Guatemala in the Spanish Colonial Period. Norman and London: University of Oklahoma Press.

Kellogg, Susan. 1995. Law and the Transformation of Aztec Culture, 15001700. Norman: University of Oklahoma Press. 
Komisaruk, Catherine. 2008. "Rape Narratives, Rape Silences: Sexual Violence and Judicial Testimony in Colonial Guatemala." Biography 31 (3): 369-96.

Landa, Fray Diego de. (1566) 2015. Relación de las cosas de Yucatán. Madrid: Ediciones Q.

Las Casas, Fray Bartolomé de. 1967. Apologética historia sumaria. 3 ed. Vol. 2. Mexico: UNAM.

Las Siete Partidas. 1807. 3 vols. Madrid: Imprenta Real.

Lynch, Joseph H. 1986. Godparents and Kinship in Early Medieval Europe. Princeton, NJ: Princeton University Press.

Margadant, Guillermo Floris. 2001. "El concepto de incesto aplicado por la justicia eclesiástica en la Nueva España y en el México independiente preliberal." In La sexofobia del clero y cuatro ensayos histórico-jurídicos sobre sexualidad, edited by Guillermo Floris Margadant, 61-95. México: Miguel Ángel Porrúa.

Maxwell, Judith M., and Robert M. Hill, II. 2006. Kaqchikel Chronicles: The Definitive Edition. Austin: University of Texas Press.

Motolinía, Fray Toribio de Benavente. 1903. Memoriales de Fray Toribio de Motolinía, edited by Luís García Pimentel. México: En casa del editor.

Novísima recopilación de las leyes en España. (1805) 2011. Charleston, SC: Nabu Press.

Penyak, Lee M. 2016. "Incestuous Natures: Consensual and Forced Relations in Mexico, 1740-1854." In Sexuality and the Unnatural in Colonial Latin America, edited by Zeb Tortorici, 162-87. Oakland: University of California Press.

Pescatello, Ann M. 1976. Power and Pawn: The Female in Iberian Families, Societies, and Cultures. Westport and London: Greenwood Press.

Recopilación de leyes de los reynos de las Indias. 1680. Madrid: Julián de Paredes.

Remesal, Fray Antonio de. (1619) 1988. Historia general de las Indias Occidentales y particular de la gobernación de Chiapa y Guatemala. 2 vols. México: Editorial Porrúa.

Restall, Matthew. 1997. The Maya World: Yucatec Culture and Society, 1550_ 1850. Stanford, CA: Stanford University Press.

Rípodas Ardanaz, Daisy. 1977. El matrimonio en Indias: realidad social y regulación jurídica. Buenos Aires: Fundación para la Educación, la Ciencia, y la Cultura.

Salazar, Ramón A. 1928. Historia de veintiún años: la independencia de Guatemala. Guatemala City: Tipografía Nacional.

Sanchiz Ochoa, Pilar. 1980. "Cambio en la estructura familiar indígena: Influencias de la Iglesia y la Encomienda en Guatemala." Revista de la Universidad Complutense 28: 169-91.

Segunda Parte de las Leyes del Reyno: Libro Sexto. 1567. Alcalá de Henares: Casa de Andrés de Angulo. https://catalog.hathitrust.org/Record/009264129

Sellers-García, Sylvia. 2014. Distance and Documents at the Spanish Empire's Periphery. Stanford, CA: Stanford University Press.

Sherman, William L. 1979. Forced Native Labor in Sixteenth-Century Central America. Lincoln and London: University of Nebraska Press.

Socolow, Susan Migden. 2015. The Women of Colonial Latin America. 2nd ed. New York: Cambridge University Press. 
Sperling, Jutta. 2004. "Marriage at the Time of the Council of Trent (1560-1570): Clandestine Marriages, Kinship Prohibitions, and Dowry Exchange in European Comparison." Journal of Early Modern History 8 (1): 67-108.

Wiesner-Hanks, Merry. 2010. Christianity and Sexuality in the Early Modern World: Regulating Desire, Reforming Practice. London and New York: Routledge.

Aquinas, Thomas. 1265-1274. Summa Theologica. Translated by Fathers of the English Dominican Province. Claremont, CA: Coyote Canyon Press. Kindle. Archibald, Elizabeth. 2001. Incest and the Medieval Imagination. Oxford: Clarendon Press.

Buffington, Robert. 2000. "Introduction: Conceptualizing Criminality in Latin America." In Reconstructing Criminality in Latin America, edited by Carlos Aguirre and Robert Buffington, xi-xix. Wilmington, DE: Scholarly Resources Inc.

Burkholder, Mark A. 1998. "Honor and Honors in Colonial Spanish America." In The Faces of Honor: Sex, Shame, and Violence in Colonial Latin America, edited by Lyman L. Johnson and Sonya Lipsett-Rivera, 18-44. Albuquerque: University of New Mexico Press.

Collins, Anne Cox. 1980. "Colonial Jacaltenango, Guatemala: The Formation of a Corporate Community.” Ph.D. diss., Tulane University.

Cortés y Larraz, Pedro. 1958. Descripción geográfico-moral de la diócesis de Goathemala. Guatemala: Tipografía Nacional.

Fox, Robin. 1980. The Red Lamp of Incest. New York: E. P. Dutton.

Gómez, Antonio. 1552. Comentarios a las Leyes de Toro. Salamanca: Andreas a Portonarijs.

Jaffary, Nora E. 2007. "Incest, Sexual Virtue, and Mobility in Late Colonial Mexico." In Gender, Race, and Religion in the Colonization of the Americas, edited by Nora E. Jaffary, 95-107. Hampshire: Ashgate.

Lavrin, Asunción. 1989. "Sexuality in Colonial Mexico: A Church Dilemma." In Sexuality and Marriage in Colonial Latin America, edited by Asunción Lavrin, 47-95. Lincoln and London: University of Nebraska Press.

McKinnon, Susan. 1995. "American Kinship/American Incest: Asymmetries in a Scientific Discourse." In Naturalizing Power Essays in Feminist Cultural Analysis, edited by Sylvia Junko Yanagisako and Carol Delaney, 25-46. New York and London: Routledge.

Nolasco de Llano, Pedro. 1785. Compendio de Los comentarios extendidos por el maestro Antonio Gómez. Madrid: Imprenta de Don Joseph Doblado. Google Books.

Peletz, Michael G. 2001. “Ambivalence in Kinship since the 1940s.” In Relative Values Reconfiguring Kinship Studies, edited by Sarah Franklin and Susan McKinnon, 413-44. Durham, NC and London: Duke University Press.

Penyak, Lee M. 2016. "Incestuous Natures: Consensual and Forced Relations in Mexico, 1740-1854." In Sexuality and the Unnatural in Colonial Latin America, edited by Zeb Tortorici, 162-87. Oakland: University of California Press.

Premo, Bianca. 2005. Children of the Father King: Youth, Authority, and Legal Minority in Colonial Lima. Chapel Hill: University of North Carolina Press.

Schwaller, Robert C. 2016. Géneros de Gente in Early Colonial Mexico: Defining Racial Difference. Norman: University of Oklahoma Press. 
Stern, Steve J. 1995. The Secret History of Gender: Women, Men, and Power in Late Colonial Mexico. Chapel Hill and London: University of North Carolina Press.

Vela y Acuña, Juan. 1603. Tractatus de Poenis Delictorum. Salamanca: Martín Pérez.

Waldron, Kathy. 1989. "The Sinners and the Bishop in Colonial Venezuela: The Visita of Bishop Mariano Martí, 1771-1784.” In Sexuality and Marriage in Colonial Latin America, edited by Asunción Lavrin, 156-77. Lincoln and London: University of Nebraska Press.

Brundage, James A. 1987. Law, Sex, and Christian Society in Medieval Europe. Chicago, IL and London: The University of Chicago Press.

Foster, George M. 1953. Cofradía and Compadrazgo in Spain and Spanish America. Southwestern Journal of Anthropology 9 (1): 1-28.

Gudeman, Stephen. 1971. "The Compadrazgo as a Reflection of the Natural and Spiritual Person." Proceedings of the Royal Anthropological Institute of Great Britain and Ireland 45-71.

Héritier, Françoise. 2002. Two Sisters and Their Mother: The Anthropology of Incest. Translated by Jeanine Herman. New York: Zone Books.

Herman, Judith Lewis. 2000. Father-Daughter Incest. Cambridge and London: Harvard University Press.

Jaffary, Nora E. 2007. "Incest, Sexual Virtue, and Mobility in Late Colonial Mexico." In Gender, Race, and Religion in the Colonization of the Americas, edited by Nora E. Jaffary, 95-107. Hampshire: Ashgate.

Lynch, Joseph H. 1986. Godparents and Kinship in Early Medieval Europe. Princeton, NJ: Princeton University Press.

Milanich, Nara. 2002. "The Children of Fate: Families, Class, and the State in Chile, 1857-1930.” Ph.D. diss., Yale University.

Paul, Benjamin D. 1942. "Ritual Kinship: With Special Reference to Godparenthood in Middle America." Ph.D. diss., University of Chicago.

Percival, Henry R. 1916. The Seven Ecumenical Councils. Vol. 14. A Select Library of Nicene and Post-Nicene Fathers of the Christian Church, Second Series. New York: The Christian Literature Company. Kindle.

Pitt-Rivers, Julian. 1958. "Ritual Kinship in Spain." Transactions of the New York Academy of Sciences 20 (5): 424-31.

Rodríguez Jiménez, Pablo. 1988. "Matrimonio incestuoso en el Medellín colonial 1700-1810.” Revista Extensión Cultural 24-25: 52-8.

Saffa, Sarah N. 2019. "She Was What They Call a "Pepe"': Kinship Practice and Incest Codes in Late Colonial Guatemala." Journal of Family History 44 (2): 181-99.

Shelton, Laura. 2007. "Like a Servant or Like a Son?: Circulating Children in Northwestern Mexico (1790-1850)." In Raising an Empire: Children in Early Modern Iberia and Colonial Latin America, edited by Ondina E. González and Bianca Premo, 219-37. Albuquerque: University of New Mexico Press.

Stern, Steve J. 1995. The Secret History of Gender: Women, Men, and Power in Late Colonial Mexico. Chapel Hill and London: University of North Carolina Press.

Yan, Yunxiang. 2001. "Practicing Kinship in Rural North China." In Relative Values: Reconfiguring Kinship Studies, edited by Sarah Franklin and Susan McKinnon, 224-45. Durham, NC and London: Duke University Press. 
Archibald, Elizabeth. 2001. Incest and the Medieval Imagination. Oxford: Clarendon Press.

Avendaño, Diego de. 1668. Thesaurus Indicus. Antwerp, Belgium: Collegÿ Societatis Jesu Monachÿ.

Bertrand, Michel. 1989. "La tierra y los hombres: la sociedad rural en Baja Verapaz durante los siglos XVI al XIX." In La sociedad colonial en Guatemala: estudios regionales y locales, edited by Stephen Webre, 141-87. Antigua, Guatemala: CIRMA.

Brundage, James A. 1987. Law, Sex, and Christian Society in Medieval Europe. Chicago, IL and London: The University of Chicago Press.

Deloria, Philip J. 2004. Indians in Unexpected Places. Lawrence: University Press of Kansas.

Diccionario de Autoridades. 1726-1739. 6 vols. Madrid: Real Academia Española. http://web.frl.es/DA.html.

Fuentes y Guzmán, Francisco Antonio de. (1690) 1882. Historia de Guatemala: ó Recordación Florida, edited by Justo Zaragoza. Madrid: Luis Navarro.

Gage, Thomas. (1648) 1958. Thomas Gage's Travels in the New World, edited by J. Eric S. Thompson. Norman: University of Oklahoma Press.

Herlihy, David. 1985. Medieval Households. Cambridge and London: Harvard University Press.

Hill, II, Robert M. 2002. Colonial Cakchiquels: Highland Maya Adaptation to Spanish Rule, 1600-1700. Belmont, CA: Thomson Wadsworth.

Kulick, Don. 1996. "Causing a Commotion.” Anthropology Today 12 (6): 3-7.

Lewis, Laura A. 1995. “'Blackness,' 'Femaleness' and Self-Representation: Constructing Persons in a Colonial Mexican Court." Political and Legal Anthropology Review 18 (2): 81-9.

Lovell, W. George, and Christopher H. Lutz. 1994. "Conquest and Population: Maya Demography in Historical Perspective." Latin American Research Review 29 (2): 133-40.

Martínez Peláez, Severo. 2009. La patria del criollo: An Interpretation of Colonial Guatemala, edited by W. George Lovell and Christopher H. Lutz. Translated by Susan M. Neve and W. George Lovell. Durham, NC and London: Duke University Press.

Merry, Sally Engle. 1994. "Courts as Performances: Domestic Violence Hearings in a Hawai'i Family Court." In Contested States: Law, Hegemony and Resistance, edited by Mindie Lazarus-Black and Susan F. Hirsch, 35-58. New York and London: Routledge.

Montenegro, Alonso de la Peña. (1668) 1771. Itinerario para párrocos de indios, en que se tratan las materias mas particulares tocantes á ellos para su buena Administración. Madrid: En la oficina de Pedro Marín. Google Books.

Scott, James C. 1990. Domination and the Arts of Resistance: Hidden Transcripts. New Haven, CT and London: Yale University Press.

Solórzano Pereira, Juan de. (1647) 1703. Política Indiana. Belgium: Henrico y Cornelio Verdussen. Google Books.

Sousa, Lisa Mary. 1997. "Women and Crime in Colonial Oaxaca: Evidence of Complementary Gender Roles in Mixtec and Zapotec Societies." In Indian Women of Early Mexico, edited by Susan Schroeder, Stephanie Wood and Robert Haskett, 199-214. Norman and London: University of Oklahoma Press. 
Taylor, William B. 1979. Drinking, Homicide, and Rebellion in Colonial Mexican Villages. Stanford, CA: Stanford University Press.

Wiesner-Hanks, Merry. 2010. Christianity and Sexuality in the Early Modern World: Regulating Desire, Reforming Practice. London and New York: Routledge.

Código civil de la república de Guatemala, 1877. 1880. Madrid: F. Gongora y Compañia. https://catalog.hathitrust.org/Record/100352263

Héritier, Françoise. 2002. Two Sisters and Their Mother: The Anthropology of Incest. Translated by Jeanine Herman. New York: Zone Books.

Komisaruk, Catherine. 2013. Labor and Love in Guatemala: The Eve of Independence. Stanford, CA: Stanford University Press.

Lynch, Joseph H. 1986. Godparents and Kinship in Early Medieval Europe. Princeton, NJ: Princeton University Press. 